\title{
Review \\ Cytokine-Mediated Crosstalk between Immune Cells and Epithelial Cells in the Gut
}

\author{
Mousumi Mahapatro, Lena Erkert and Christoph Becker*
}

check for updates

Citation: Mahapatro, M.; Erkert, L.; Becker, C. Cytokine-Mediated Crosstalk between Immune Cells and Epithelial Cells in the Gut. Cells 2021, 10, 111. https://doi.org/10.3390/ cells10010111

Received: 9 December 2020 Accepted: 7 January 2021 Published: 9 January 2021

Publisher's Note: MDPI stays neutral with regard to jurisdictional clai$\mathrm{ms}$ in published maps and institutional affiliations.

Copyright: (C) 2021 by the authors. Licensee MDPI, Basel, Switzerland. This article is an open access article distributed under the terms and conditions of the Creative Commons Attribution (CC BY) license (https:// creativecommons.org/licenses/by/ $4.0 /)$.

\author{
Department of Medicine 1, Friedrich-Alexander-University Erlangen-Nuremberg, 91052 Erlangen, Germany; \\ mousumi.mahapatro@uk-erlangen.de (M.M.); lena.erkert@uk-erlangen.de (L.E.) \\ * Correspondence: christoph.becker@uk-erlangen.de
}

\begin{abstract}
Cytokines are small proteins that are secreted by a vast majority of cell types in the gut. They not only establish cell-to-cell interactions and facilitate cellular signaling, but also regulate both innate and adaptive immune responses, thereby playing a central role in genetic, inflammatory, and infectious diseases of the gut. Both, immune cells and gut epithelial cells, play important roles in intestinal disease development. The epithelium is located in between the mucosal immune system and the gut microbiome. It not only establishes an efficient barrier against gut microbes, but it also signals information from the gut lumen and its composition to the immune cell compartment. Communication across the epithelial cell layer also occurs in the other direction. Intestinal epithelial cells respond to immune cell cytokines and their response influences and shapes the microbial community within the gut lumen. Thus, the epithelium should be seen as a translator or a moderator between the microbiota and the mucosal immune system. Proper communication across the epithelium seems to be a key to gut homeostasis. Indeed, current genome-wide association studies for intestinal disorders have identified several disease susceptibility loci, which map cytokine signatures and their related signaling genes. A thorough understanding of this tightly regulated cytokine signaling network is crucial. The main objective of this review was to shed light on how cytokines can orchestrate epithelial functions such as proliferation, cell death, permeability, microbe interaction, and barrier maintenance, thereby safeguarding host health. In addition, cytokine-mediated therapy for inflammation and cancer are discussed.
\end{abstract}

Keywords: cytokines; signaling; inflammation; immunity; gut homeostasis; IBD

\section{Introduction}

The intestinal tract is a complex organ of the human body and multitasks a variety of functions, which include nutrient absorption, digestion, waste excretion, barrier regulation, and host-microbiome interactions. The majority of the gut tissue is comprised of epithelial cells and immune cells, making it the largest immune organ of the human body. Communication between these two cell types is crucial for maintaining homeostasis and responding to external threats that can lead to disease [1].

Intestinal epithelial cells (IECs) form a single strong monolayer that barricades the luminal and microbial contents from the resident immune cells. IECs have a very short life-span of about 4-5 days, after which they are shed at the villus tip and are renewed from the crypt bottom in a tightly controlled manner. However, this single epithelial cell layer is more complex in its composition and dynamic in its functions, a property that is essential for regulating physiology and pathophysiology of the gut. The majority of IECs are absorptive enterocytes followed by specialized cell types like antimicrobial peptideproducing Paneth cells (restricted to the small intestine only), mucus-producing goblet cells, hormone-secreting enteroendocrine cells, M (microfold)-cells, and tuft cells. All IEC cell types originate from $\operatorname{Lgr} 5+$ stem cells that reside deep in the crypts of the large and small intestine. IECs regularly interact with neighboring immune cells and are, similar to immune cells, able to secrete molecules like cytokines, chemokines, and growth factors [1]. 
Intestinal immune cells are mostly reserved in the gut-associated lymphoid tissues like Peyer's patches, lymphoid follicles, and cryptopatches. However, a diverse array of immune cells are also present in the lamina propria (LP) or intermingled in the monolayer of epithelial cells. The LP contains cells of both, the innate and the adaptive immune system, like macrophages, dendritic cells, mast cells, T-cells, B-cells, innate lymphoid cells (ILC), etc., whereas the epithelium, in contrast, only predominantly harbors T-cells (intraepithelial lymphocytes (IELs)). The spatial orientation of epithelial cells allows antigen recognition on its apical side to sense danger signals and transmit this information to the underlying LP immune cells that respond by secreting cytokines in order to restore the balance in the intestine [2]. Nonetheless, these cytokines can act positively or negatively, e.g., macrophages can signal IL-10 during colonic damage that helps in restoration of homeostasis, but also IL- $1 \beta$ or TNF- $\alpha$, which can contribute to an enhancement of intestinal inflammation. Additionally, there are many conflicting data in the literature that show specific cytokines like IL-33 have both pro- and anti-inflammatory properties. Besides their role in inflammation, gut cytokines also participate in cell proliferation, cell death, safe-guarding tight junctions, and recruitment of immune cells to the site of infection [3]. Moreover, recent in vitro advancements in organoid culture have made it feasible to study the precise interaction of specific cytokines with epithelial cells as opposed to the oldfashioned method of using 2D cell lines. The aim of this review was to discuss recent advances in intestinal immune-epithelial crosstalk and to shed light on the complex interplay of cytokines and how they respond to threats during health and disease, with a prospect of targeting cytokines as novel treatment.

\section{Tranquility in the Gut: Cytokines Maintaining Homeostasis}

Intestinal homeostasis is maintained by a complex interplay among the epithelium, immune factors and the microbial flora. Cytokines support intestinal homeostasis by governing key cellular processes like cell death, proliferation, molecular transport, and inflammatory responses against pathogens [4]. Constitutively active cytokines that regularly shuttle among different compartments of the intestinal mucosa can modulate the division of epithelial cells and assign appropriate immune cells to establish feedback loops.

Cytokines from the IL-1 family, like IL-1 $\beta$ and IL-18, play a crucial role in maintaining homeostatic conditions in the intestine (Figure 1) [5]. The release of these two cytokines is dependent on the activation of the inflammasome complex, whereas IL- $1 \beta$ secretion is stimulusdriven and IL-18 is constitutively expressed by the intestinal epithelium [6]. Nonetheless, a strict equilibrium of the IL-18 level is important for epithelial integrity as overexpression of IL-18 in this compartment leads to a loss of matured goblet cells and increased susceptibility to experimental colitis. On the other hand, deletion of IL-18 in IECs confers protection against DSS-induced colonic inflammation [6]. Interestingly, epithelial-derived IL-18 can directly act on IL-18R1-expressing CD4+ Th17 cells as well as Foxp3+ regulatory T-cells (Tregs) and can control their differentiation during both homeostasis and inflammation [7]. In this case, IL-18 portrays a perfect example of cytokine-mediated crosstalk, where the intestinal epithelium educates immune cells for the necessary action. Vice versa, IL-22, a member of the IL-10 family, has been shown to be primarily secreted from immune cells and can directly affect the intestinal epithelium via its receptors [8]. IL-22 is secreted from T-cells and innate lymphoid cells (ILCs). Tissue resident Th1 and Th17 cells can secrete IL-22 under the influence of IL-6 and IL-23, which on the other hand can be inhibited by TGF- $\beta$ [9-11]. Additionally, IL-12 and IL-17 can also induce Th1 cells to secrete IL-22. Other sources of IL-22 include Th22 cells, CD8+ T-cells, $\gamma \delta$ T-cells, and NKT cells under homeostatic and inflammatory conditions, e.g., during Citrobacter rodentium infection [12]. These cell populations are in close contact with the IECs that abundantly express the receptor for IL-22 (IL-22RA1) [13]. Indeed, stimulation of IL-22 on intestinal epithelial derived organoids leads to an increase in their size and proliferation rate [13]. This was supported in a study by Zwarycz et al. using IL22 transgenic mice, which also showed an increased number of Ki67+ IECs and increased crypt length [14]. Mechanistically, IL-22 activates STAT3 signaling that promotes epithelial 
cell survival during bacterial infection by secretion of antimicrobial peptides like Reg3 $\beta$ and Reg3 $\gamma$ [15]. Thus, IL-22 plays a key role in the regulation of mucosal homeostasis.

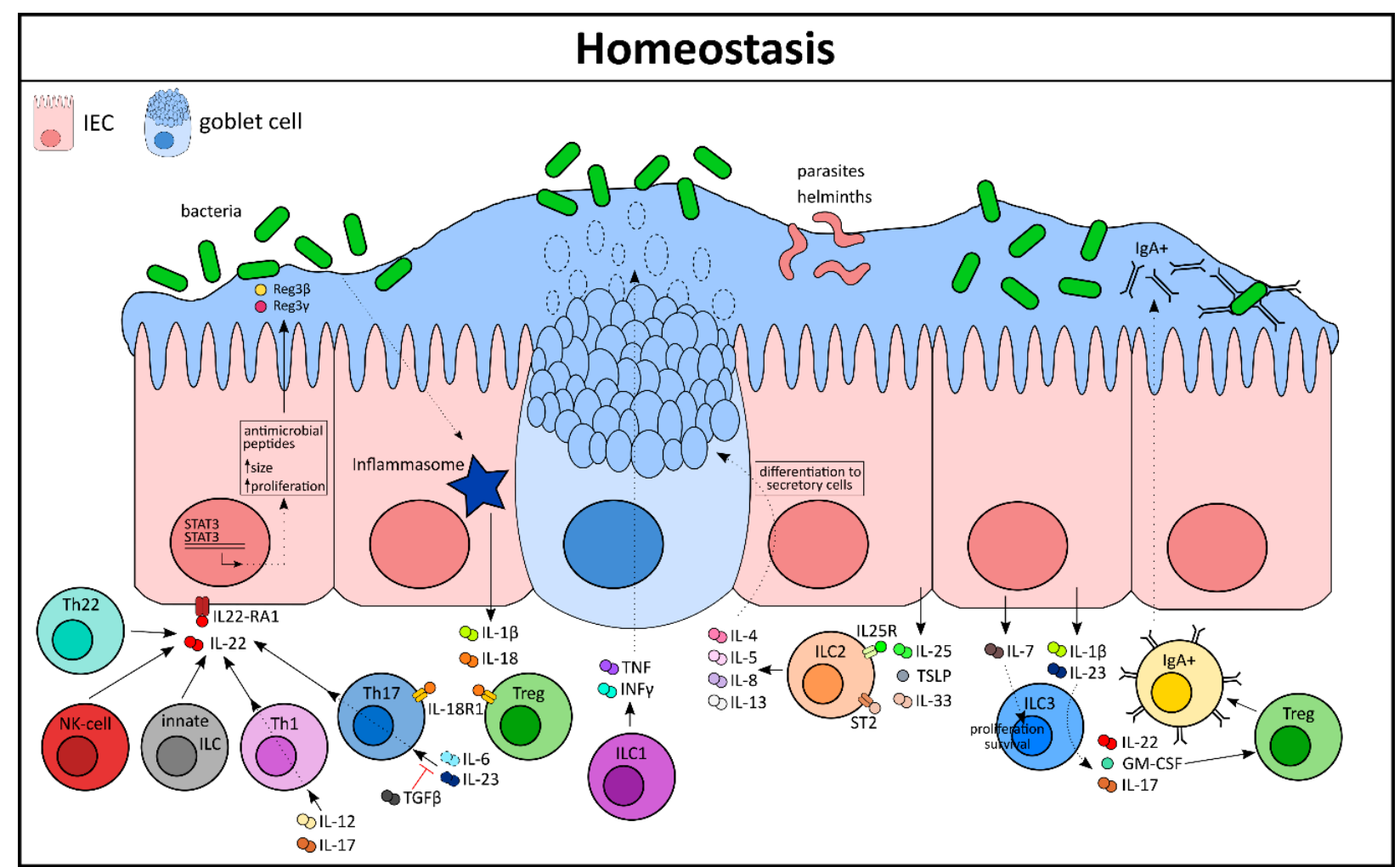

Figure 1. Immune-epithelial crosstalk as a guardian of intestinal homeostasis. GM-CSF, granulocyte-macrophage colonystimulating factor; IEC, intestinal epithelial cell; ILC, innate lymphoid cell; NK-cell, natural killer cell; STAT, signal transducers and activators of transcription; Th, T helper cell; Treg, regulatory T-cell; TSLP, thymic stromal lymphopoietin.

Among the innate cells of the LP, ILCs act as first responders during tissue injury. The ILCs exhibit a similar phenotype and function as T-lymphocytes, but lack the lineage markers expressed by T-cells. They have been shown to play a crucial role in the maintenance of tissue homeostasis by several independent research groups (reviewed extensively in [16]). ILCs mediate their actions primarily by fine tuning cytokine networks between the innate and adaptive immune system. ILCs arise from the common lymphoid progenitor and categorize into three major subsets: ILC1, ILC2, and ILC3, which mirror phenotypically to Th1, Th2, and Th17 lymphocytes, respectively [17]. In humans, ILCs are distributed heterogeneously across the gastrointestinal tract with a gradual increase in their frequency from the proximal to the distal intestine, indicating their functional properties as tissue specific [18]. The T-bet expressing ILC1 population has been shown to be the main producer of TNF and IFN- $\gamma$ in an immune defense against Salmonella enterica or Toxoplasma gondii infection (Figure 1). Moreover, ILC1s drive secretion of mucus from goblet cells, thereby restoring the epithelial barrier $[19,20]$.

ILC2s are primarily involved in controlling parasitic infections in the gut and serve as an excellent example of crosstalk between epithelial and innate immune cells. During infection, parasites and helminths are in close contact with epithelial cells and elicit the secretion of a copious amount of certain cytokines like IL-25, IL-33, and TSLP (Figure 1). These epithelial-derived cytokines can directly signal to the ILC2 population that bears its receptors (IL-25R and ST2) to secrete type 2 family cytokines like IL-5, IL-13, IL-4, and IL-9. In turn, these cytokines have the ability to reorganize the epithelial cell compartment by inducing differentiation of progenitor cells to cells of the secretory lineage like the goblet cells [16]. A high number of mucus-producing goblet cells helps in the eradication of the parasite from its host. This positive feedback loop amplifies the type 2 immune 
response to establish homeostasis, which is mediated exclusively by cytokines. ILC2s also respond to eicosanoids, such as prostaglandin D2 (PGD2) and leukotriene D4, to secrete type 2 cytokines. However, this finding has been mostly studied in inflamed lung tissue. A similar working mechanism has yet to be elucidated in the gut [21]. Although much less is known about human ILC2s, they have been found in many different places such as in the peripheral blood, fetal tissues, and the adult gut [22].

ILC3s, together with lymphoid tissue inducer (Lti) cells, are vital for the organogenesis of secondary lymphoid organs during fetal development and are identified by the expression of the surface receptor ROR $\gamma$ t. They are abundantly present in the gastrointestinal tract and are, notably, the most characterized ILC population to take part in intestinal homeostasis. It has been implicated that IL-7 can modulate the survival and proliferation of ILC3 by increasing the expression of ROR $\gamma \mathrm{t}[23,24]$. In fact, studies with IL-7 reporter mice have confirmed that it can be secreted by EpCAM+ IECs and this expression is controlled by the commensal microbiota of the healthy gut [25]. Other than that, IL-1 $\beta$ and IL-23 have been shown to be robust stimulators for ILC3, compelling the secretion of effector cytokines like IL-22, GM-CSF, and IL-17 [26]. ILC3-derived IL-22 plays a major role in mounting an innate response and reshaping the microbiota after a pathogenic invasion of bacteria like Citrobacter rodentium and Clostridium difficile [27,28]. Similarly, ILC3-derived IL-17 has been shown to be crucial against opportunistic pathogens like Candida albicans in the oral mucosa. Indeed, mice lacking the ILC3 population are more susceptible to bacterial infections and are often rendered incapable of controlling a pathogen invasion, possibly due to the fact that in these mice the IECs have an impaired antimicrobial peptide production [16]. GM-CSF, another important regulator secreted by ILC3, acts like a cytokine and controls intestinal Tregs. Intestinal Tregs are crucial for homeostasis as they control effector cell responses in the gut as well as the selection of immunoglobulin A (IgA) plasma cells, thereby supporting tissue repair [29].

Additionally, ILC3 can directly mediate fucosylation of IECs by inducing expression of intestinal epithelial enzymes like Fut1 and Fut2 (fucosyltransferase enzymes). This is an important mechanism that enables IECs to survive harmoniously within the commensals [30]. Collectively, it is clear that even under homeostatic conditions there is constant crosstalk between the immune and the epithelial cells mediated by a composed cytokine network (Figure 1).

\section{Intestinal Microbiota Influences Cytokine Production}

A diverse microbiome in the intestine is essential for maintaining a robust immune system and homeostasis at the epithelial barrier. The host and the microbial commensals have a symbiotic relationship, where the host provides the required nutrients to facilitate microbial survival and the microbes secrete components that not only prevent colonization of extrinsic pathogens but also support intestinal repair through the promotion of cellular proliferation and differentiation [31]. Changes in the microbial composition induced by diet, alcohol, antibiotics intake, or pre-existing genetic aberrations can lead to dysbiosis in the gut and deregulation of cytokine signatures. A functional consequence of dysbiosis is the initiation of immune-related diseases, including inflammatory bowel diseases (IBD) [32]. Microbes interact with IECs via pattern recognition receptors (PRRs), like Toll-like receptors (TLRs) [33], and its adaptor myeloid differentiation primary response protein 88 (MYD88) [34] and NOD-like receptors (NLRs) [35,36], NOD-, LRR-, and pyrin domain-containing 6 (NLRP6) (Figure 2) [36]. Of note, NLRP6 deficiency has been shown to induce an altered microbiota, reduction in levels of IL-18, intestinal hyperplasia, and colonic enteritism underlining the crucial relationship between the microbiota and homeostasis $[37,38]$. 


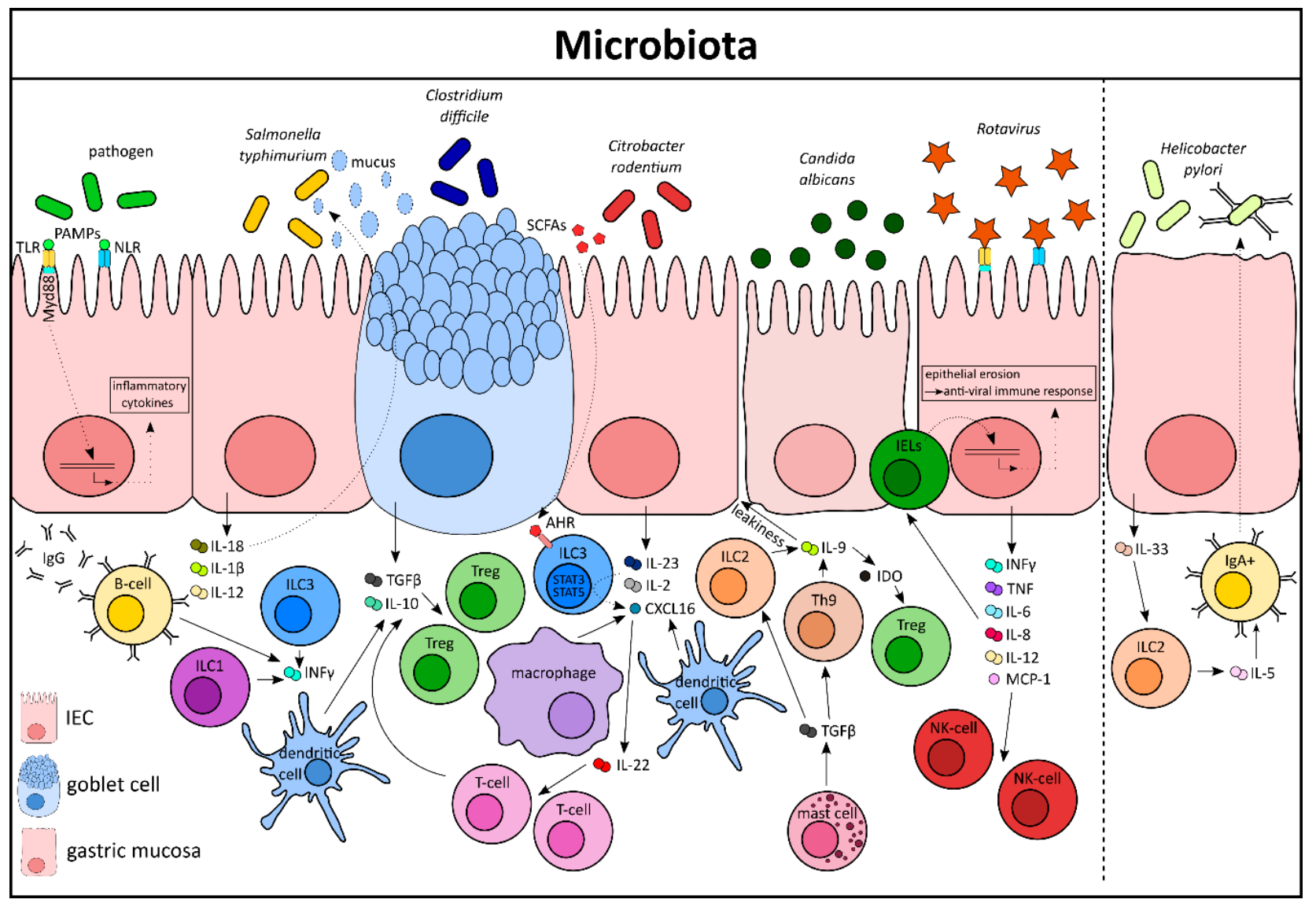

Figure 2. Cytokine signaling between intestinal epithelial cells and immune cells regulate the host response to infections. AHR, Aryl hydrocarbon receptor; IDO, indolamin-2,3-dioxygenase; IELs, intraepithelial lymphocytes; MCP-1, monocyte chemoattractant protein-1; NLR, NOD-like receptor; PAMPs, pathogen-associated molecular patterns; SCFAs, short-chain fatty acids; TLR, Toll-like receptor.

The complex microbiota is an amalgamation of a multispecies community comprising of bacteria, fungi, viruses, archaea, and protozoans. After a bacterial invasion, a complex cascade of signals initiate the release of cytokines, chemokines, acute phase proteins and other effectors of the humoral immunity [39]. For example, IL-18 functions as a pleiotropic cytokine that can induce enterocytes to produce more AMPs and goblet cells to produce more mucus in order to eradicate pathogens like Salmonella Typhimurium (Figure 2) [40]. A recent interesting study linked IL-18 to the microbiota and the central nervous system by showing enteric neurons to be the major producers of this cytokine, other than IECs and immune cells [41]. Salmonella gastroenteritis infection results in the release of IL-1 $\beta$ and IL-12 that can induce ILC1s and B-cells to secrete high levels of IFN- $\gamma$ and IgG antibodies, respectively $[19,42]$. Additionally, NCR3+ (natural cytotoxicity receptor) ILC3s have been shown to play a crucial role in both Salmonella and Listeria monocytogenes infections, in a Runt-related transcription factor 3 (Runx3)-dependent manner, modulating IFN- $\gamma$ secretion [43]. Certain bacterial species from the Clostridiales family, like Clostridium difficile, can educate goblet cells and CD103+ dendritic cells (DCs) to secrete TGF- $\beta$ and IL-10, thereby generating ample signals to increase the Treg population. DCs and T-cells can also sense Clostridium-derived metabolites, like short chain fatty acids (SCFA) and tryptophan, to induce proliferation of Tregs [44]. However in Rag1-/- mice that lack T- and B lymphocytes, the ILC3s are the major responders during Clostridium infection, producing IL-22, IL-33, TNF, Nos2, IL-17a, and Reg3 $\gamma$ [42]. Indeed, ILCs and natural killer (NK) cells show high levels of plasticity when it comes to tackling certain bacterial infections like Citrobacter rodentium, a mouse-specific pathogen that mimics the disease symptoms caused by the human pathogens enteropathogenic Escherichia coli (EPEC) and enterohaem- 
orrhagic Escherichia coli (EHEC). Both ILC1s and NK cells promote bacterial clearance by producing IFN- $\gamma$, TNF, and IgG in the colon, which contribute to homing of CD4+ T-cells to the intestine [45]. However, in the initial phase of a Citrobacter infection, IL-22 producing ILC3s are activated via their surface receptors (aryl hydrocarbon receptor (AHR), ROR $\gamma \mathrm{t}$, Vitamin A and D receptors) or bacteria derived metabolites (SCFAs, Butyrate), which eventually leads to recruitment of T-cells and subsequent bacterial clearance [46-49]. Additionally, crosstalk among myeloid cells like CX3CR1+ DCs, TL1A+ macrophages, and ILC3s mediates the release of the chemokine CXCL16 and controls the expression of IL-22 and antimicrobial peptides (AMPs) [50-52]. Mechanistically, STAT5a, STAT5b, and STAT3 signaling, initiated by IL-2 or IL-23, respectively, in ILC3 has been shown to play a major role in Citrobacter-mediated colitis [53]. In contrast, infection with the stomach residing pathogen Helicobacter pylori can induce Tregs and ILC2s to elicit a specific TCR repertoire that drives T-cell polarization [44]. Indeed, infection with Helicobacter leads to the release of IL-33 from gastric mucosa and subsequent activation of ILC2s, which can secrete IL-5 and enhance the IgA release by B-cells [54-56]. This mechanism partially contributes to protection against the infection [57].

Fungi, like Candida albicans, are part of the human gastrointestinal tract microbiota. However, excessive colonization of Candida in the gut can lead to unspecific chronic disorders like fatigue, diarrhea, allergies, and skin irritation [58]. A recent study showed IL-9 and mast cells to be key players in Candida pathogenesis (Figure 2). TGF- $\beta$ released from mast cells activates Th9 cells and ILC2s to secrete IL-9, which pivotally contributes to immune tolerance via the indoleamine 2, 3-dioxygenase enzyme (IDO). However, Candida-driven IL-9 also leads to a disruption of the epithelial barrier and increases leakiness in the gut, leading to inflammation [59]. Of note, differences in the gut fungal microbiota composition are associated with mucosal inflammation and disease activity in IBD patients [60].

Interferons (IFN) are critical mediators for antimicrobial host responses. Type II IFNs (IFN- $\gamma$ ) are mostly associated with providing protection against a broad range of intracellular microorganisms, whereas Type I (IFN- $\alpha$, IFN- $\beta$ ) and type III (IFN- $\lambda 1,-\lambda 2$, and $-\lambda 3$ ) IFNs primarily mediate antiviral responses. IFN receptors (IFNR) are highly expressed by IECs and receptor-ligand interaction leads to activation of the JAK/STAT pathway and expression of IFN-stimulated genes [61]. Viruses, like Rotavirus, are a common cause for gastroenteritis and exhibit strong epithelial aberrations in the small intestine of infected patients [62]. In fact, mice deficient for IFNR in the IEC compartment (Ifnlr $1^{-1-}$ mice) are more susceptible to viral infections $[63,64]$. On a mechanistic level, Rotavirus activates PRRs expressed by both IECs and DCs, like Toll-like receptor 3 (TLR3), Retinoic acidinducible gene-I (RIG-I), and melanoma differentiation-associated gene-5 (MDA-5), which leads to the secretion of proinflammatory cytokines like IFN, TNF, IL-6, IL-8, IL-12, and MCP-1. These aforementioned cytokines lead to collateral damage by recruiting cells of both innate and adaptive immunity, most notably CD3+NK1.1+CD $8 \alpha \alpha+$ IELs, which, in turn, results in epithelial damage and mucosal erosion followed by an antiviral state in IECs [65] (Figure 2).

Hence, a comprehensive study of the microbial composition, microbe-derived metabolites, host factors interacting with the microbiota, and the underlying complex interactions with immune and epithelial cells is vital for analyzing multiple aspects of intestinal diseases.

\section{Cytokine Regulation in Intestinal Pathology}

Intestinal diseases can affect any part of the gut, starting from the proximal duodenum through to the rectum. It is associated with many complications, like constipation, irregular bowel movement, or abdominal pain, that compromise the overall health and lifestyle of an individual. Etiological studies have identified common factors like increased epithelial permeability, dysbiosis, inflammation, visceral hypersensitivity, immune cell infiltration, and altered brain-gut interactions. Prevalent gastrointestinal diseases are IBS (irritable bowel syndrome), Celiac disease, and IBD (inflammatory bowel diseases) [66]. 


\subsection{Irritable Bowel Syndrome and Celiac Disease}

IBS is a gastrointestinal disorder with a global prevalence of $11.2 \%$ [67]. Clinical symptoms of IBS mimic other bowel diseases and are associated with abdominal pain or discomfort, stool irregularities, and bloating [68]. The systematic circulating cytokine profile of patients suffering from IBS has been studied, but the implications of these findings on mucosal immunity remain inconclusive. For example, in vitro experiments using peripheral blood mononuclear cell (PBMC) cultures from IBS patients showed a reduced secretion of IL-10 [69,70], an anti-inflammatory cytokine, and an elevated level of proinflammatory cytokines like IL-1 $\beta$, IL-6, IL-8, IL-12, and TNF at steady state conditions [69-71]. Additionally, in some studies, cytokines such as chemokine (C-C motif) ligand-16 (CCL-16) [72], macrophage migration inhibitory factor (MIF), and monocyte chemotactic protein-1 (MCP1 or CCL2) [73] were found to be elevated in the serum of IBS patients compared with controls. In fact, polymorphisms in genes encoding inflammatory cytokines have been reported in IBS patients [74], including SNPs in the IL-6 region, which occur during the progression of the disease, and indicate an increased risk with cytokine dysfunction [75]. Unfortunately, at present, little is known about how these findings translate to immuneepithelial communication in the gut, and further mechanistic studies would be required to better understand the pathophysiology of IBS.

Celiac disease is an autoimmune disorder of the gut that primarily affects the small intestine and is induced by the ingestion of gluten in the diet [76]. The genetic predisposition to this protein that can elicit an intestinal enteropathy is still unknown. IECs are the first cells to be in contact with the gluten or gluten-derived components like gliadin and are responsible for mounting an adaptive immune reaction at the effector site (e.g., the lamina propria) by secreting IL-15 [77]. IL-15 alters epithelial barrier functions by disrupting the tight junction protein Zonulin [78], thereby increasing permeability $[79,80]$. Subsequently, IL-15 can also induce IELs to secrete IFN- $\gamma$, which can activate T-cells like CD4 $+\alpha / \beta$ and CD8 $+\alpha / \beta$ cells to acquire an aberrant NK-like phenotype that can kill enterocytes in a T-cell receptor (TCR)-independent manner. This unique pathway facilitates an increased gluten/gliadin uptake that ultimately results in villous atrophy in the mucosa of celiac disease patients [81,82]. IECs also secrete transglutaminase 2 (TG2) and autoantibodies generated against this enzyme can be detected in celiac patients. Autoantibody levels are positively correlated with the disease severity [83]. In summary, the cytokine profile in this disease is predominantly proinflammatory and a failure to control the inflammatory response may be one of the factors underlying gluten intolerance in genetically predisposed individuals $[84,85]$.

\subsection{Inflammatory Bowel Diseases}

The etiology of inflammatory bowel diseases (IBDs) still remains unknown, but there has been mounting evidence that it is associated with an abnormal microflora, unregulated immune responses, genetic susceptibility, and lifestyle choices. IBD is broadly categorized into Crohn's disease (CD) and ulcerative colitis (UC). In UC, inflammation is mostly confined to the colon, whereas in CD it can affect many parts of the gastrointestinal tract, often leading to strictures and fistulas. Extraintestinal manifestations, like joint pain, psoriasis, ankylosing spondylitis, or primary sclerosing cholangitis (PSC), are frequently diagnosed in both forms of IBD [16,86]. Genome-wide association studies (GWAS), mouse models of colitis, and in vitro organoid experiments from murine and human gut tissue have greatly advanced the understanding of the molecular mechanisms involved in cytokine signaling and immune-epithelial interactions and their impact on mucosal inflammation [87]. In the present scenario, it is clear that a perturbed cytokine cascade amplifies inflammation.

On a cellular level, activated lamina propria cells secrete a plethora of cytokines at the local site of inflammation, including proinflammatory cytokines (TNF, IFN- $\gamma$, IL-6, IL-12, IL-21, IL-23, IL-17, integrins, etc.), as well as anti-inflammatory cytokines (IL-10, TGF $\beta$, IL-35, etc.) [88]. CD is usually designated as a type 1 driven disease with an elevated production and activation of Th1 and Th17 cells and their cytokines like IL-12, IL-23, IFN- $\gamma$, 
and IL-17. In contrast, UC has been associated with a type 2-like inflammation, as indicated by an increased production of Th2 and Th9 cells and cytokines like IL-13, IL-5, and IL-9 (Figure 3) [88]. Interestingly, IL-23 has been shown to be associated with both CD and UC pathology. An increased production of IL-23 by macrophages, dendritic cells, and granulocytes has been observed in various mouse models of colitis and in IBD patients. IL23 mediates activation and cytokine production of other immune cells in colitis, such as NK cells, IELs, ILCs, and Th17, while simultaneously blocking the activation of Tregs. Genetic studies have identified single nucleotide polymorphisms in the IL-23R gene in IBD patients, suggesting that IL-23R signaling affects disease susceptibility [89]. Similar to IL-23, another cytokine from the same family, IL-12 is also implicated in IBD pathology. It is predominantly secreted by DCs, monocytes, and macrophages after pathogen recognition via Toll-like receptors. IL-12 induces the production of IFN- $\gamma$ by promoting the differentiation of Th1, thereby forming a link between innate and adaptive immunity [90,91]. The role of IL-27 in IBD is more complex as it has been shown to be both pro- and anti-inflammatory in nature [92]. On one hand, exogenous administration of IL-27 via food or subcutaneous injection led to inhibition of Th17 cells and amelioration of TNBS-induced colitis, eventually decreasing the intestinal inflammation with a reduced pathologic score and inflammatory cytokines $[93,94]$. On the other hand, IL-27R $\alpha^{-/-}$mice developed less severe colitis after DSS treatment when compared to their wild-type controls, characterized by reduction in inflammatory cytokines (IL-6, TNF, and IFN- $\gamma$ ). Additionally, in another model of T-cellmediated colitis, transfer of IL-27R $\alpha^{-/-}$T-cells resulted in diminished weight loss and reduced intestinal inflammation when compared to transferring wild-type T-cells [95].

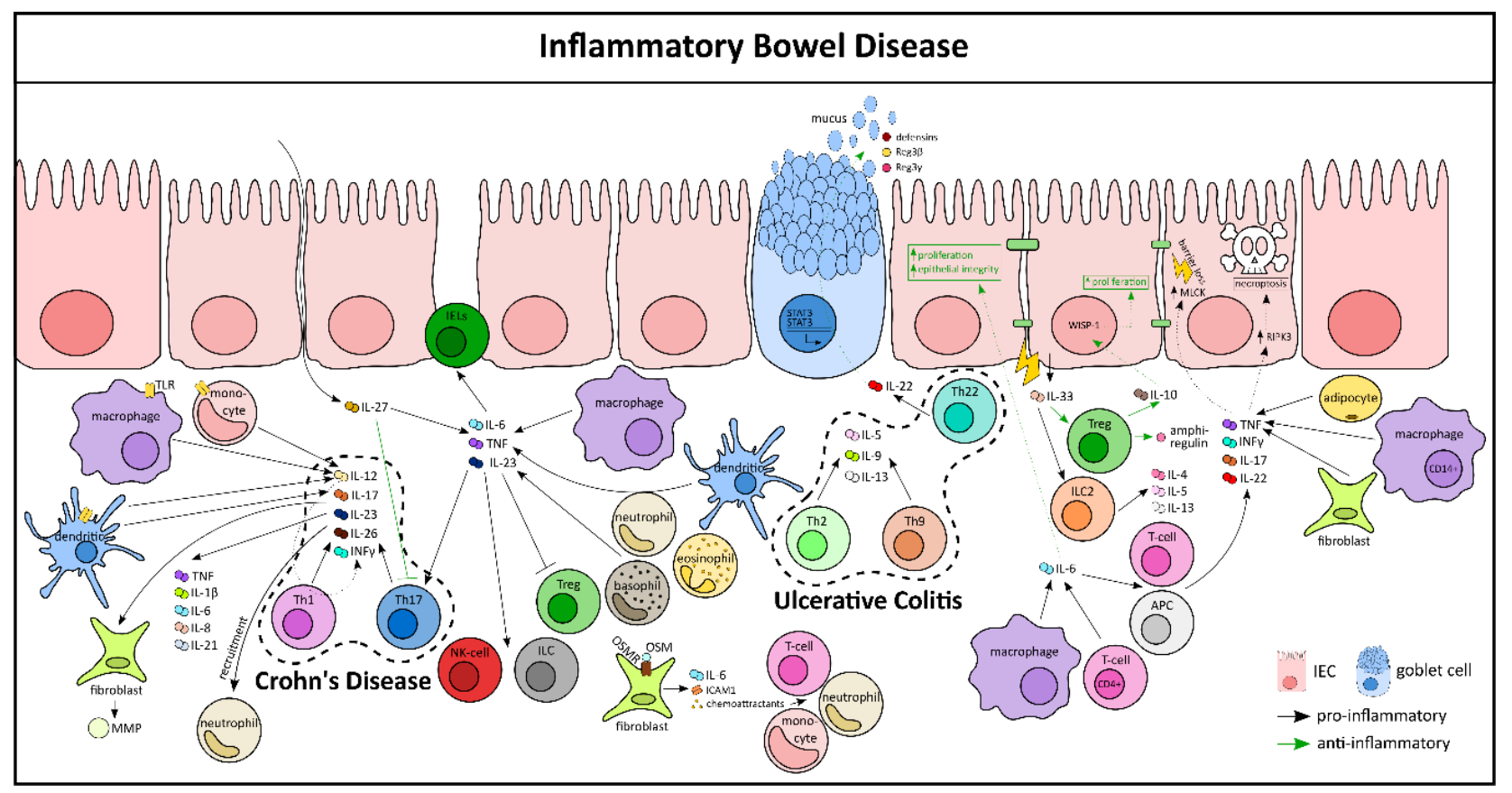

Figure 3. Cytokine-mediated immune-epithelial crosstalk in inflammatory bowel diseases. APC, antigen-presenting cell; ICAM, intercellular adhesion molecule-1; MLCK, myosin light chain kinase; MMP, matrix metalloproteinase; OSM, Oncostatin M; OSMR, Oncostatin M receptor; RIPK3, receptor interacting serine/threonine kinase 3; WISP-1, WNT 1inducible signaling pathway protein 1 .

Both IL-6 and TNF are central regulators in IBD pathogenesis. IL-6 is majorly produced by macrophages and CD4+ T-cells in the inflamed mucosa of mice and in human colons (Figure 3) [96]. IL-6 exerts its proinflammatory functions by activating multiple cells, including antigen-presenting cells (APC) and T-cells and their signature cytokines (IFN- $\gamma$, TNF, IL-17, IL-22 etc.). Besides its proinflammatory function, IL-6 has an important role in restoring homeostasis in IECs by stimulating their proliferation [96]. In fact, during an 
ongoing inflammation, the expansion of IECs is crucial for the intestinal barrier function as closure of the eroded area is the key to the resolution process. Hence, mucosal healing is critically dependent on cytokines released in its near vicinity, like TNF. Experimental studies have shown that membrane-bound TNF, rather than soluble TNF, has a major role in driving intestinal inflammation. TNF is mainly produced by CD14+ macrophages, adipocytes, fibroblasts, and T-cells from patients with IBD [97,98]. TNF signaling in IECs of the terminal ileum results in Paneth cell necroptosis via RIPK3 [99]. In murine models of experimental colitis, TNF signaling increased MLCK expression, resulting in tight junction dysregulation and barrier loss in the IEC compartment [100]. Of note, IL-6 and IL-23 also activate T-cells, like Th17, to produce their signature cytokines, such as IL-17A, IL-17F, and IL-26. Functionally, Th17-secreted cytokines were found to mediate proinflammatory responses, like the upregulation of TNF, IL-1 $\beta$, IL-6, IL-21, and IL-8; the recruitment of neutrophils; and the secretion of matrix metalloproteinases (MMP) by intestinal fibroblasts [101-103]. These findings suggest that Th17-secreted cytokines contribute to tissue destruction in IBD. Interestingly, Th22 effector cells are abundant in patients with UC, but not in CD patients. These cells produce anti-inflammatory cytokines, such as IL-22, that participate in epithelial cell proliferation, wound healing, and the production of antimicrobial proteins, such as defensins and mucins, as well as REG3 $\beta$ and REG3 $\gamma$ proteins via STAT3 activation [104]. In support of a protective function of IL-22, it was demonstrated that IL-22 treatment can protect mice from T-cell-dependent colitis [105].

Another pleiotropic cytokine, IL-33, along with its receptor, ST2, has been associated with IBD risk loci genes and is shown to be upregulated in UC patients [106,107]. IL-33 is also increased in the colonic mucosa of both TNBS- and DSS-induced murine colitis. $\mathrm{ST} 2^{-/-}$mice exhibit reduced disease severity in colitis models and administration of exogenous IL-33 aggravates the disease. This is associated with a marked elevation of IL-4, IL-5, and IL-13; a significant reduction of IL-17 and IFN- $\gamma$; impairment of the epithelial barrier; and a delay of wound healing of the injured colonic epithelium [108-112] (Figure 3). In sharp contradiction, IL-33 has also been shown to protect against intestinal inflammation by activating Foxp3+ Tregs and ILC2 cells and by the production of amphiregulin [113,114]. These contrasting animal experimental results indicate the complicated role of IL-33 in IBD, and hence, require further investigation. A recent interesting study showed the cytokine oncostatin M (OSM) to be highly upregulated in inflamed mucosal tissue of IBD patients [115] The OSM receptor (OSMR) is expressed by nonhematopoietic and nonepithelial intestinal stromal cells, which respond to OSM by producing various pro-inflammatory molecules, including IL-6, the leukocyte adhesion factor ICAM1, and chemokines that attract neutrophils, monocytes, and T-cells [116]. However, in a counter regulatory mechanism, OSM promotes epithelial repair during inflammation [117].

In recent years it has been unanimously consolidated that loss-of-function mutations in the genes encoding IL-10 and the IL-10 receptor are associated with very early onset IBD. For instance, mice deficient in the anti-inflammatory cytokines IL-2 or IL-10 develop spontaneous colitis [96]. Intestinal Tregs are the major producers of IL-10, which exerts its protective function on epithelial cells by inducing proliferation and by stimulating synthesis of Wnt1-inducible signaling protein-1 (WISP-1) (Figure 3) [118]. Interestingly, gut microbiota seemed to play a crucial role in the development of colitis in this mouse model, as germ-free IL-10 ${ }^{-/-}$mice did not develop colitis and the administration of antibiotics prevented colitis. Indeed, it has been narrowed down to a single species, Helicobacter hepaticus, which is responsible for this exacerbated disease in this model [119]. Collectively, it is now clear that cytokines have a fundamental role in IBD pathogenesis. Hence, blocking proinflammatory cytokines or using recombinant anti-inflammatory cytokines were initiated to treat patients with IBD (Figure 3).

\subsection{Cytokine Networks in Colorectal Cancer}

Colorectal cancer (CRC) is, like any other cancer, a complex disease with a high prevalence globally. Malignant epithelial cancer cells are supported by the tumor microenvironment, which includes various immune cells, cancer-associated fibroblasts, and 
circulating cytokines $[120,121]$, many of which have been demonstrated to promote CRC progression [122]. Cytokines promoting tumorigenesis are IL-4, IL-6, IL-8, IL-11, IL-17A, IL-22, IL-23, IL-33, TNF- $\alpha$, TGF- $\beta$, and VEGF (vascular endothelial growth factor), whereas cytokines with antitumorigenic properties are IFN- $\gamma$, IL-12, IL-15, IL-17F, and IL-18. The contribution of the cytokines IL-1, IL-9, IL-10, IL-21, and GM-CSF to CRC development and progression remains unclear [122].

The protumorigenic role of IL-4 is evident from experimental mouse models of CRC using AOM/DSS. It has been shown that IL-4- or IL-4R-deficient mice develop far less tumors than their control counterparts [123]. However, a type 2 signature, including IL-5, IL13, and IL-9, seems to have no prognostic advantage in CRC patients [124]. T-lymphocytes and IELs are the major source of IL-4 in cancer tissue (Figure 4) [125]. With a very high expression of IL-4R $\alpha$ on malignant IECs [126], IL-4 signaling leads to phosphorylation of the signal transducer and activator of transcription 6 (STAT6) in IECs, as well as in other hematopoietic cells [127]. Of note, STAT6 phosphorylation is an essential biomarker in the prediction and prognosis of CRC patients [128]. In CRC patients with distant metastases, IL-4 serum levels were increased when compared with patients without metastases [129]. Similarly, IL-6 has also been shown to be upregulated at both serum- [129] and expressionlevels in CRC tissues. In the AOM/DSS animal model, IL-6 deletion led to ameliorated tumor development. In fact, IL-6 trans-signaling is critical for IEC survival, a phenomenon that malignant cells take advantage of, thereby facilitating tumor progression $[130,131]$. This in turn leads to activation of STAT3, which negatively correlates with the survival of CRC patients [132]. It is noteworthy that cytokines like IL-23, VEGF, IL-17, and IL-22 work in synergy when it comes to CRC tissues [133]. IL-23 levels were enhanced in tumor tissue and IL-23a ${ }^{-/-}$mice developed fewer tumors when compared to controls in an Apc $\mathrm{Ain}^{\mathrm{N}+}$ animal model of intestinal carcinogenesis [134]. While dendritic cells, macrophages, and neutrophils remain the main source of IL-23, once released it can exert its effect on both T-lymphocytes and ILCs to produce secondary cytokines like IL-17A and IL-22 [135,136]. These secondary cytokines, together with IL-23, can activate NF-kB, STAT3 [137], and STAT5 [138] signaling in malignant IECs. It is now well established that IL-22 supports intestinal stem cells or stemness of IECs. In a recent publication from Gronke K et al. it has been shown that stem cells deprived of IL-22 signaling were more likely to give rise to colon cancer when exposed to carcinogens like AOM. A possible mechanism for this observation is by escaping DDR (DNA damage response)-controlled apoptosis [139]. ILC3s and $\gamma \delta$ T-cells are the major source of IL-22, which in turn can lead to the activation of the transcription factor STAT3 and therefore the expression of histone 3 lysine 79 (H3K79) methytransferase DOT1L. This complex induces a few stem cell genes like NANOG, SOX2, and Pou5F1, resulting in increased stemness and tumorigenic potential [140]. Likewise, in the AOM/DSS experimental model, both VEGF and its receptor VEGFR2 were strongly upregulated and treatment with anti-VEGF reduced tumor progression [141]. Similarly, inhibition of VEGFR in Apc Min/+ animals resulted in reduced tumor burden [142]. VEGF is known to be secreted by many cells, such as cancer-associated fibroblasts, platelets, and mast cells, and VEGFR1 signaling in IECs can activate Wnt/ $\beta$-catenin signaling, an important regulator in cancer progression [143]. 


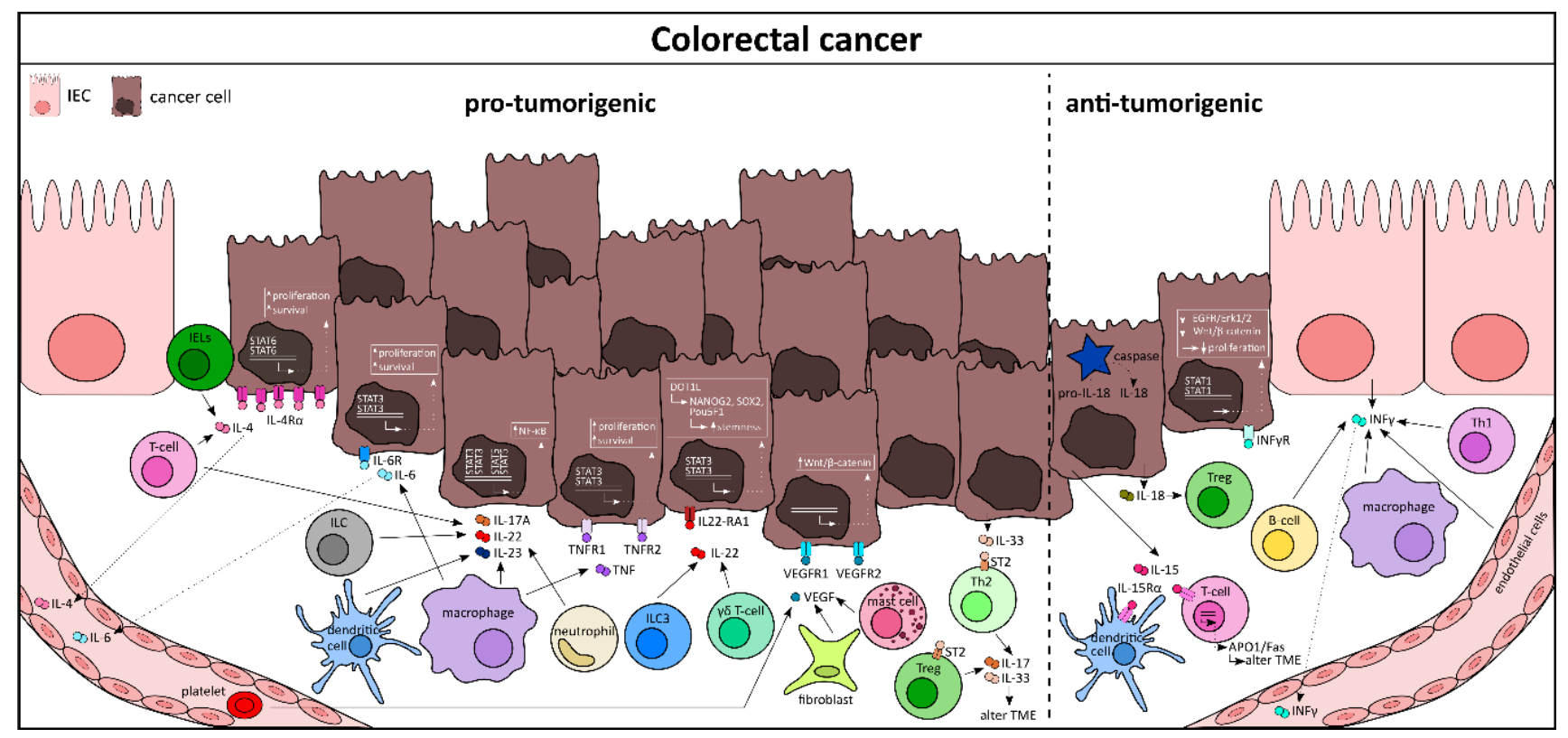

Figure 4. Cytokine signaling between intestinal epithelial cells and immune cells as a regulator of colorectal cancer development. TME, tumor microenvironment.

Colorectal cancer is sometimes the consequence of prolonged and recurrent inflammation in the gut (colitis-associated colorectal cancer or CAC), especially in UC patients [144]. The cytokine profile in these patients acts as a decisive factor in the tumor progression and metastases [145]. A few cytokines, like TNF and IL-6, have been shown to be the driving factors that bridge these two diseases (reviewed in [146]). Activated macrophages are able to produce TNF, which then binds to TNFR (both 1 and 2) expressed by IECs and other hematopoietic cells $[147,148]$. Activation of the TNFR leads to phosphorylation of STAT3 and/or induction of the NK-kB signaling cascade, similar to that of IL-6, which supports malignant cell survival and proliferation [149]. The deleterious effect of TNF is confirmed by using both animal models of CRC (Apc $\mathrm{Cin} /+^{+}$and AOM/DSS), where abrogation of TNF signaling strongly diminished tumor growth [150]. Additionally, TNF has also been shown to promote tumor growth and metastasis via induction of epithelial-derived oncogene MACC1 [145]. Certain cytokines, like IL-33, a member of the IL-1 family, can regulate CRC progression by controlling the tumor microenvironment (TME). IL-33 is highly expressed by epithelial cells within adenomas and cancer cells, whereas the expression of the IL-33 receptor (ST2) can be localized predominantly on both stromal cells and epithelial cells [151]. Genetic ablation of IL-33 signaling in Apc $\mathrm{Ain} /+^{+}$mice or inhibition by using neutralizing antibodies led to reduced proliferation, increased apoptosis and diminished angiogenesis in polyps, which overall reduced the tumor burden [152]. ST2 is also expressed by immune cells like Th2 cells [153] and Foxp3+ Tregs [154]. By releasing cytokines like IL-17 and IL-33, the recruited immune cells are able to remodel the epithelium [155] and organize the TME to promote malignancy. In addition, both IL- 8 and IL- 11 are also characterized as protumorigenic [122]. IL-8 mainly acts on myeloid cells and signals through its receptor CXCR1/2 to activate the Akt and MAPK pathways to promote the expression of genes responsible for cell proliferation, invasion, and angiogenesis [156]. IL-11, on the other hand, exerts its protumorigenic effects by activating TGF- $\beta$ and driving a STAT3-dependent cascade to promote cancer [157,158].

One might hypothesize that the cancer progression and promotion is determined by the ratio of pro- versus antitumorigenic cytokines at a given time point. As a mechanism to counter tumor development, the host tries to eradicate the malignant cells by evoking an antitumor immune response and a wide range of cytokines with antitumor functions. For example, a higher level of IFN- $\gamma$ in the serum of CRC patients is correlated with the absence of nodal metastases and thus a better prognosis (Figure 4) [159]. The 
protective role of IFN- $\gamma$ in clinical cases is supported by results obtained from animal models of cancer, where deletion of IFN- $\gamma$ (Ifng ${ }^{-/-}$mice) shows a higher tumor burden when compared to controls [160]. IFN- $\gamma$ is produced by many cell types in the cancer tissue, most notably the Th1 cells, B-cells, macrophages, and endothelial and epithelial cells [161]. Mechanistically, IFN- $\gamma$ signaling, via its receptor (IFN $\gamma$ R), induces STAT1 phosphorylation and inhibits the EGFR/Erk1/2 and Wnt/ $\beta$-catenin signaling pathways, thereby decreasing cell proliferation in tumor epithelial cells [161]. Similarly, IL-15 has also been implicated for its antitumorigenic role in several mouse models of cancer $[162,163]$. At the molecular level, IL-15 released from epithelial cells binds to IL-15R $\alpha$ expressing myeloid cells (dendritic and CD8+ T-cells), which activate the APO-1/FAS- or granulemediated cytotoxic pathway [164]. Another IL-1 superfamily cytokine, IL-18, plays a major role in gastrointestinal cancer as well. Pro-IL-18 is constitutively expressed by many cell types of the gut, including epithelial cells. Mature IL-18 is processed from its preform in a caspase-dependent manner and is secreted from the inflammasome complex [165]. IL-18 restricts Th17 differentiation and promotes the expression of effector molecules from Tregs, thereby mediating host immunity [7]. Indeed, mice deficient for IL-18 or its receptor (IL-18r1) develop more tumors upon AOM/DSS treatment, compared with wild-type controls [166]. Additionally, IL-18 and IL-12 work in synergy to activate type 1 immune responses by controlling the DNA damage protein ADP-ribosyltransferase diphteria toxinlike 1 (ARTD1) and subsequent IFN- $\gamma$ production by myeloid cells [167]. Contrary to IL-17A, its family member, IL-17F, has been implicated in antitumorigenic activity. IL-17F knock out mice appear to develop more neoplastic lesions than wild-type mice upon the administration of AOM/DSS [168]. In this model IL-17F inhibited tumor angiogenesis by regulating VEGF [169]. However, a recent report highly contradicted this finding by suggesting IL-17F as an oncogene in CRC [170]. Additionally, loss of the IL-17 receptor $\mathrm{D}$ has been shown to promote inflammation-associated tumorigenesis [171]. At present, additional research is needed to elucidate the role of different IL-17 family cytokines in colon cancer in order to strategize therapy.

Collectively, there is no doubt that cytokines released in the TME play an essential role in CRC development and progression [172]. Identifying complex cytokine network signatures at different stages of the disease can help in designing precision medication more efficiently [173]. Combinatorial drugs that target multiple cytokines hold great promise for the future (Figure 4).

\section{Cytokine-Mediated Therapy for Gut Diseases}

As previously described, immune-epithelial cell interactions, mediated by numerous cytokines, play a crucial role in the pathogenesis of various gut diseases. Therefore, targeting of such cytokines is considered a rational approach to treating intestinal diseases.

Existing approaches for CRC therapy are well-established adjuvants like FOLFOX4 (fluorouracil/folinic acid, oxaliplatin) and FOLFIRI (folinic acid, fluorouracil, irinotecan). Future approaches of CRC therapy might focus on the complex cytokine network in order to specifically target and inhibit cancer cells by altering the TME. One of the first FDAapproved cytokine-targeted immunotherapies in the field of CRC is bevacizumab, an anti-VEGF antibody (Figure 5). In a first study, CRC patients treated with bevacizumab showed a longer median overall survival when combined with FOLFOX4 [174] and, in a second study when it was added to chemotherapy treatment, it improved progression-free survival [175]. However, in contrast to the first study, in the second study, bevacizumab exhibited no beneficial increase of the overall survival, leading to a lot of discrepancy. Similarly, the VEGF inhibitor, aflibercept, could also show improved overall median survival in CRC patients when combined with FOLFIRI chemotherapy [176]. 


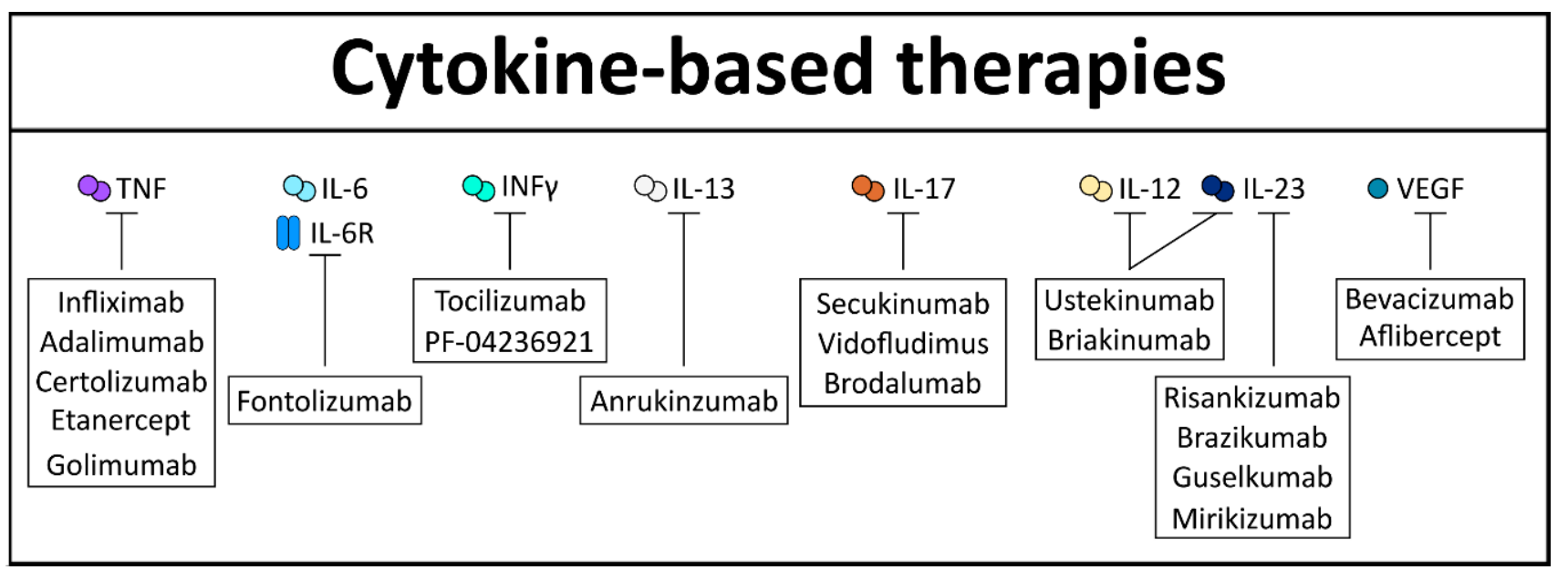

Figure 5. Monoclonal antibodies developed for targeting cytokines in intestinal diseases.

With regard to IBD, TNF inhibition is of especial interest, since it is considered a crucial driver of intestinal inflammation. In fact, different publications have shown the positive effect of TNF inhibition on experimental induced murine colitis [177]. One of the first-inclass TNF inhibitors approved for the treatment of IBD is infliximab, a monoclonal antibody, considered effective in both UC and CD [178,179]. Indeed, infliximab established a classical example of proof-in-concept, where blocking of a single cytokine was effective against an immune mediated disorder [180]. Later on, these beneficial effects led to the invention of various other TNF inhibitors that target the membrane-bound and/or soluble form of TNF with different affinities. Among them are adalimumab, certolizumab, etanercept, and golimumab. However, in the ensuing years, several patients failed to respond or lost the response to these inhibitors due to immunogenicity against the compound [181]. Additionally blocking of TNF signaling increases the risk for the development of infectious disease, since TNF is an important driver in pathogen clearance as well [182]. Of note, TNF blockers/ inhibitors have been shown to reduce the frequency of CAC in treated IBD patients, although bigger IBD cohorts are necessary to confirm this initial observation [183].

The limitations of TNF therapy ignited the research for finding alternative anticytokine therapies for intestinal diseases. In this regard, another promising target was IL-6 or its receptor IL-6R. Indeed, inhibition of this signaling cascade has been shown to effectively diminish murine induced colitis $[131,184]$. Clinical trials using the IL-6R inhibitor tocilizumab exhibited clinical efficacy in CD patients [185] who were unresponsive to TNF inhibition [186]. Unfortunately, IL-6 inhibition leads to severe side effects, like the development of abscesses or perforation, as demonstrated with the IL-6 inhibitor PF-04236921 [186]. Furthermore, it has been shown that IL-18 blockade, by using either neutralizing anti-murine IL-18 antiserum [187] or by the administration of an adenovirus expressing IL-18 antisense mRNA [188], diminishes inflammation in murine models of colitis. This, however, needs to be analyzed further, since no clinical trials for anti-IL-18 therapy have been initiated so far. Interestingly, IL-12 and IL-23 share the p40 subunit and targeting this subunit simultaneously has been shown to be an effective target in intestinal inflammation. Many clinical trials were performed with ustekinumab, a general p40 inhibitor, exhibiting great efficacy in CD patients, even in patients who were intolerant to TNF inhibition [189-191], including long-term efficacy and safety [192]. In contrast, another anti-IL12/IL-23p40 targeting antibody, called briakinumab, showed a lack of efficacy in the treatment of intestinal inflammation, probably due to increased immunogenicity when compared with ustekinumab [193]. Notably, specific neutralization of the IL-23 subunit p19 could abrogate colitis in different inflammatory animal models [194-196]. Recently, clinical trials supporting these observations, by using risankizumab, a selective monoclonal humanized antibody against IL-23p19, showed remission in patients with CD [197]. Furthermore, brazikumab, which also specifically inhibits IL-23p19, was tested in CD patients 
and could show first beneficial effects in a phase 2a clinical study [198]. Two relatively new IL-23p19-targeting biologicals are guselkumab and mirikizumab, both currently in phase 2 clinical trials for CD and UC. First results of mirikizumab in the treatment of UC are promising [199] and encourage further investigations, as cytokine-mediated therapies for UC are less common than for CD. Similarly, fontolizumab, an anti-INF- $\gamma$ antibody in a phase 2 study, showed promising therapeutic effects in active $C D$ patients by demonstrating increased rates of clinical response and remission compared with placebo [200].

However, targeting cytokines in intestinal pathogenesis has also shown some failure. Indeed, IL-13 inhibitors, like anrukinzumab, exhibited no statistically significant changes of disease severity in UC patients [201]. Comparably, anti-IL-17 therapeutics, like secukinumab or vidofludimus, have failed to reduce intestinal inflammation, and even worsened the inflammatory burden [202,203]. These results were also confirmed by using brodalumab, a human monoclonal antibody targeting IL-17RA [204]. However, these negative results led to the observation that IL-17 is a really important cytokine for intestinal homeostasis, wound repair, and barrier function $[205,206]$.

Taken together, these studies indicate that our understanding for cytokine functions and its downstream mediators has significantly increased over the years. Cytokine blockade or augmentation will remain a crucial strategy for IBD and cancer therapy. However, there is still a need to optimize specific targets and establish stable delivery systems in order to ensure effective clinical therapy in the future (Figure 5).

\section{Conclusions}

This review sheds light on cytokines as crucial moderators in the maintenance of intestinal homeostasis. The multifunctional and complex nature of cytokines enables them to participate in key regulatory mechanisms in the gut, like cellular proliferation, cell death, safe-guarding of epithelial tight junctions, maintenance of a healthy microbial flora, etc. (Table 1 and Table S1). Despite decades of scientific research in cytokine signaling by using animal models of infection, IBD and cancer are still lacking in the characterization and role of single cytokines on immune-epithelial interactions. A possible solution for this aforementioned dilemma is to utilize the organoid technology and elucidate both the secretome and proteome of epithelial cells after stimulation with cytokines or bacteriaderived metabolites. This will establish a clear connection among the individual cytokine, microbiota, immune cells, and epithelial alteration in a synchronized manner.

Table 1. A list of major cytokines in intestinal health and pathology along with their specific functions.

\begin{tabular}{|c|c|c|c|}
\hline Cytokine & Cellular Source(s) & Target Cell(s) & Function \\
\hline IL-22 & ILC, Th22, NK cell, Th1, Th17 & IECs & $\begin{array}{c}\text { Activation of STAT3 signaling and } \\
\text { release of AMPs }\end{array}$ \\
\hline IL-1 $\beta$ & IECs & $\mathrm{M} \phi$, Endothelial cells & Activation of T-cells and ILCs \\
\hline IL-18 & IECs & Th17, Tregs & $\begin{array}{c}\text { IEC proliferation, tissue regeneration, } \\
\text { production of proinflammatory } \\
\text { cytokines }\end{array}$ \\
\hline IL-6 & IECs, fibroblasts, $\mathrm{M} \phi$ & Th17, IELs, IECs & $\begin{array}{l}\text { IEC proliferation and repair, activation } \\
\text { of STAT3, crypt homeostasis }\end{array}$ \\
\hline IL-23 & IECs, M $\phi$, DC & IELs, ILC3, NK cell, T-cells & $\begin{array}{l}\text { Proinflammatory cytokine secretion } \\
\text { contributes to chronic inflammation }\end{array}$ \\
\hline IL-12 & Monocyte, $\mathrm{M} \phi, \mathrm{DC}$ & Th1 & $\begin{array}{l}\text { T-cell survival and differentiation, } \\
\text { proliferation of NK cell }\end{array}$ \\
\hline IL-17A & Th1, ILC3 & IECs & $\begin{array}{c}\text { Antimicrobial response, maintenance of } \\
\text { homeostasis }\end{array}$ \\
\hline TNF & ILC1, M $\phi$ & IECs & $\begin{array}{l}\text { Epithelial cell death, epithelial cell } \\
\text { migration during wound healing, } \\
\text { mucosal repair during inflammation }\end{array}$ \\
\hline
\end{tabular}


Table 1. Cont.

\begin{tabular}{|c|c|c|c|}
\hline Cytokine & Cellular Source(s) & Target Cell(s) & Function \\
\hline INF- $\gamma$ & ILC1, M $\phi$ & IECs, DC, Tregs & $\begin{array}{l}\text { Confers protection against pathogens, } \\
\text { activation of STAT1 signaling, } \\
\text { disruption of epithelial barrier }\end{array}$ \\
\hline
\end{tabular}

TGF- $\beta \quad$ IECs, DC, Tregs, Mast cells $\quad$ B-cells, Th9 cells, M $\phi$

Expansion of Tregs, IgA secretion, IEL development, tight junction maintenance

Differentiation of IECs to secretory cells, confers protection against intestinal

IL-4 ILC2, Th2, IECs, Mast cells

parasite infection, survival of malignant cells, activation of STAT6 signaling

IL-5 ILC2, Th2, B-cells IECs, B-cells, Eosinophills

Differentiation of IECs to secretory cells, confers protection against intestinal parasite infection

\begin{tabular}{|c|c|c|c|}
\hline IL-9 & ILC2, Th9 & IECs & $\begin{array}{l}\text { Differentiation of IECs to secretory } \\
\text { cells, leakiness in gut barrier }\end{array}$ \\
\hline IL-13 & ILC2, Th2 & IECs & $\begin{array}{l}\text { Differentiation of IECs to secretory } \\
\text { cells, mucin production, confers } \\
\text { protection against intestinal parasite } \\
\text { infection, activation of STAT6 signaling }\end{array}$ \\
\hline IL-25 & IECs & ILC2, T-cells & $\begin{array}{l}\text { Host protection against intestinal } \\
\text { helminthes, type } 2 \text { immune response }\end{array}$ \\
\hline TSLP & IECs, Mast cells, DC & Th2 cells, ILC2 & $\begin{array}{c}\text { Type } 2 \text { immune response, } \mathrm{T} \text { - and B-cell } \\
\text { activation }\end{array}$ \\
\hline IL-33 & IECs, intestinal myofiboblasts & ILC2, Tregs, Th2 cells IECs & $\begin{array}{c}\text { Type } 2 \text { immune response, IEC } \\
\text { differentiation, intestinal inflammation }\end{array}$ \\
\hline IL-7 & IECs & ILC3, Tregs, T effector cells & $\begin{array}{l}\text { Proinflammatory cytokine secretion, } \\
\text { IEC homeostasis }\end{array}$ \\
\hline GM-CSF & T cells, ILC3 & Monocyte, M $\phi$, Tregs & $\begin{array}{l}\text { M } \phi \text { differentiation, } \operatorname{IgA} \text { secretion from } \\
\text { B-cells, bacterial clearance, epithelial } \\
\text { repair during wound healing }\end{array}$ \\
\hline IL-2 & T cells & Th1, Tregs & $\begin{array}{c}\text { Activation of STAT3/5 signaling, } \\
\text { differentiation of T-cells, intestinal } \\
\text { homeostasis }\end{array}$ \\
\hline IL-10 & M $\phi$, Tregs & IECs & $\begin{array}{l}\text { Intestinal homeostasis, IEC } \\
\text { proliferation }\end{array}$ \\
\hline IL-11 & $\mathrm{M} \phi$ & Malignant IECs & $\begin{array}{l}\text { Activation of JAK/STAT signaling, } \\
\text { tumor cell survival }\end{array}$ \\
\hline IL-15 & IECs & T-cells, IELs & $\begin{array}{l}\text { Epithelial barrier disruption, } \\
\text { antitumorigenic functions }\end{array}$ \\
\hline OSM & T cells, DC & Stromal cells & $\begin{array}{l}\text { Proinflammatory cytokine secretion, } \\
\text { activation of JAK/STAT signaling }\end{array}$ \\
\hline Areg & Tregs, ILC2 & IECs & Tissue repair after damage, fibrosis \\
\hline VEGF & $\begin{array}{l}\text { Stromal cells, Mast cells, } \\
\text { Platelets }\end{array}$ & IECs & $\begin{array}{l}\text { Malignant cell survival, angiogenesis, } \\
\text { intestinal stem cell proliferation }\end{array}$ \\
\hline
\end{tabular}

(IL-interleukin; INF-interferon; TNF-tumor necrosis factor; TGF-transforming growth factor; TSLP—thymic stromal lymphoprotein; GM-CSF-granulocyte-macrophage colony-stimulating factor; OSM-oncostatin M; Areg-amphiregulin; VEGF-vascular endothelial growth factor; AMP—antimicrobial peptides; IEC—intestinal epithelial cells; IEL—intraepithelial lymphocytes; DC—dendritic cells; M $\phi$-macrophages; ILC—innate lymphoid cells). 
Supplementary Materials: The following are available online at https:/ / www.mdpi.com/2073-4 409/10/1/111/s1, Table S1: A list of major cytokines in intestinal health and pathology along with their specific functions.

Author Contributions: M.M., L.E., and C.B. drafted the manuscript. L.E designed the figures. All authors proofread and approved the final manuscript. All authors have read and agreed to the published version of the manuscript.

Funding: This research received funding from the TRR241 (A03), the SFB1181 (C05), and the Interdisciplinary Center for Clinical Research (IZKF) of the University Erlangen-Nuremberg (J80).

Conflicts of Interest: The authors declare no conflict of interest

\section{References}

1. Peterson, L.W.; Artis, D. Intestinal epithelial cells: Regulators of barrier function and immune homeostasis. Nat. Rev. Immunol. 2014, 14, 141-153. [CrossRef] [PubMed]

2. Burgueño, J.F.; Abreu, M.T. Epithelial Toll-like receptors and their role in gut homeostasis and disease. Nat. Rev. Gastroenterol. Hepatol. 2020, 17, 263-278. [CrossRef] [PubMed]

3. Friedrich, M.; Pohin, M.; Powrie, F. Cytokine Networks in the Pathophysiology of Inflammatory Bowel Disease. Immunity 2019, 50, 992-1006. [CrossRef] [PubMed]

4. Rathinam, V.A.; Chan, F.K.-M. Inflammasome, Inflammation, and Tissue Homeostasis. Trends Mol. Med. 2018, $24,304-318$. [CrossRef] [PubMed]

5. Palomo, J.; Dietrich, D.; Martin, P.; Palmer, G.; Gabay, C. The interleukin (IL)-1 cytokine family-Balance between agonists and antagonists in inflammatory diseases. Cytokine 2015, 76, 25-37. [CrossRef] [PubMed]

6. Nowarski, R.; Jackson, R.; Gagliani, N.; De Zoete, M.R.; Palm, N.W.; Bailis, W.; Low, J.S.; Harman, C.C.D.; Graham, M.; Elinav, E.; et al. Epithelial IL-18 Equilibrium Controls Barrier Function in Colitis. Cell 2015, 163, 1444-1456. [CrossRef] [PubMed]

7. Harrison, O.J.; Srinivasan, N.; Pott, J.W.R.; Schiering, C.; Krausgruber, T.; Ilott, N.E.; Maloy, K.J. Epithelial-derived IL-18 regulates Th17 cell differentiation and Foxp3+ Treg cell function in the intestine. Mucosal Immunol. 2015, 8, 1226-1236. [CrossRef] [PubMed]

8. Shohan, M.; Dehghani, R.; Khodadadi, A.; Dehnavi, S.; Ahmadi, R.; Joudaki, N.; Houshmandfar, S.; Shamshiri, M.; Shojapourian, S.; Bagheri, N. Interleukin-22 and intestinal homeostasis: Protective or destructive? IUBMB Life 2020, 72, 1585-1602. [CrossRef]

9. Liang, S.C.; Tan, X.-Y.; Luxenberg, D.P.; Karim, R.; Dunussi-Joannopoulos, K.; Collins, M.; Fouser, L.A. Interleukin (IL)-22 and IL-17 are coexpressed by Th17 cells and cooperatively enhance expression of antimicrobial peptides. J. Exp. Med. 2006, 203, 2271-2279. [CrossRef]

10. Zheng, Y.; Danilenko, D.M.; Valdez, P.A.; Kasman, I.; Eastham-Anderson, J.; Wu, J.; Ouyang, W. Interleukin-22, a TH17 cytokine, mediates IL-23-induced dermal inflammation and acanthosis. Nature 2006, 445, 648-651. [CrossRef]

11. Rutz, S.; Noubade, R.; Eidenschenk, C.; Ota, N.; Zeng, W.; Zheng, Y.; Hackney, J.; Ding, J.; Singh, H.; Ouyang, W. Transcription factor c-Maf mediates the TGF-beta-dependent suppression of IL-22 production in T(H)17 cells. Nat. Immunol. 2011, 12, 1238-1245. [CrossRef] [PubMed]

12. Satoh-Takayama, N.; Vosshenrich, C.A.J.; Lesjean-Pottier, S.; Sawa, S.; Lochner, M.; Rattis, F.; Mention, J.-J.; Thiam, K.; Cerf-Bensussan, N.; Mandelboim, O.; et al. Microbial Flora Drives Interleukin 22 Production in Intestinal NKp46+ Cells that Provide Innate Mucosal Immune Defense. Immunity 2008, 29, 958-970. [CrossRef] [PubMed]

13. Lindemans, C.A.; Calafiore, M.; Mertelsmann, A.M.; O'connor, M.H.; Dudakov, J.A.; Jenq, R.R.; Velardi, E.; Young, L.F.; Smith, O.M.; Lawrence, G.; et al. Interleukin-22 promotes intestinal-stem-cell-mediated epithelial regeneration. Nature 2015, 528, 560-564. [CrossRef] [PubMed]

14. Zwarycz, B.; Gracz, A.D.; Rivera, K.R.; Williamson, I.A.; Samsa, L.A.; Starmer, J.; Daniele, M.A.; Salter-Cid, L.; Zhao, Q.; Magness, S.T. IL22 Inhibits Epithelial Stem Cell Expansion in an Ileal Organoid Model. Cell. Mol. Gastroenterol. Hepatol. 2019, 7, 1-17. [CrossRef]

15. Zheng, Y.; Valdez, P.A.; Danilenko, D.M.; Hu, Y.; Sa, S.M.; Gong, Q.; Abbas, A.R.; Modrusan, Z.; Ghilardi, N.; De Sauvage, F.J.; et al. Interleukin-22 mediates early host defense against attaching and effacing bacterial pathogens. Nat. Med. 2008, 14, 282-289. [CrossRef]

16. Geremia, A.; Arancibia-Cárcamo, C.V. Innate Lymphoid Cells in Intestinal Inflammation. Front. Immunol. 2017, 8, 1296. [CrossRef]

17. Spits, H.; Artis, D.; Colonna, M.; Diefenbach, A.; Di Santo, J.P.; Eberl, G.; Koyasu, S.; Locksley, R.M.; McKenzie, A.N.J.; Mebius, R.E.; et al. Innate lymphoid cells-A proposal for uniform nomenclature. Nat. Rev. Immunol. 2013, 13, 145-149. [CrossRef]

18. Krämer, B.; Goeser, F.; Lutz, P.; Glässner, A.; Boesecke, C.; Schwarze-Zander, C.; Kaczmarek, D.J.; Nischalke, H.D.; Branchi, V.; Manekeller, S.; et al. Compartment-specific distribution of human intestinal innate lymphoid cells is altered in HIV patients under effective therapy. PLoS Pathog. 2017, 13, e1006373. [CrossRef]

19. Klose, C.S.; Kiss, E.A.; Schwierzeck, V.; Ebert, K.; Hoyler, T.; d'Hargues, Y.; Göppert, N.; Croxford, A.L.; Waisman, A.; Tanriver, Y.; et al. A T-bet gradient controls the fate and function of CCR6-RORgammat+ innate lymphoid cells. Nature 2013, 494, 261-265. [CrossRef] 
20. Klose, C.S.; Flach, M.; Möhle, L.; Rogell, L.; Hoyler, T.; Ebert, K.; Fabiunke, C.; Pfeifer, D.; Sexl, V.; Fonseca-Pereira, D.; et al. Differentiation of Type 1 ILCs from a Common Progenitor to All Helper-like Innate Lymphoid Cell Lineages. Cell 2014, 157, 340-356. [CrossRef]

21. Mjösberg, J.; Spits, H. Human innate lymphoid cells. J. Allergy Clin. Immunol. 2016, 138, 1265-1276. [CrossRef] [PubMed]

22. Huang, Y.; Paul, W.E. Inflammatory group 2 innate lymphoid cells. Int. Immunol. 2015, 28, dxv044-8. [CrossRef] [PubMed]

23. Yang, J.; Cornelissen, F.; Papazian, N.; Reijmers, R.M.; Llorian, M.; Cupedo, T.; Coles, M.; Seddon, B. IL-7-dependent maintenance of ILC3s is required for normal entry of lymphocytes into lymph nodes. J. Exp. Med. 2018, 215, 1069-1077. [CrossRef] [PubMed]

24. Forkel, M.; Mjösberg, J. Dysregulation of Group 3 Innate Lymphoid Cells in the Pathogenesis of Inflammatory Bowel Disease. Curr. Allergy Asthma Rep. 2016, 16, 73. [CrossRef] [PubMed]

25. Hara, T.; Shitara, S.; Imai, K.; Miyachi, H.; Kitano, S.; Yao, H.; Tani-Ichi, S.; Ikuta, K. Identification of IL-7-Producing Cells in Primary and Secondary Lymphoid Organs Using IL-7-GFP Knock-In Mice. J. Immunol. 2012, 189, 1577-1584. [CrossRef]

26. Maloy, K.J.; Kullberg, M.C. IL-23 and Th17 cytokines in intestinal homeostasis. Mucosal Immunol. 2008, 1, 339-349. [CrossRef] [PubMed]

27. Sonnenberg, G.F.; Monticelli, L.A.; Elloso, M.M.; Fouser, L.A.; Artis, D. CD4+ Lymphoid Tissue-Inducer Cells Promote Innate Immunity in the Gut. Immunity 2011, 34, 122-134. [CrossRef]

28. Gladiator, A.; Wangler, N.; Trautwein-Weidner, K.; LeibundGut-Landmann, S. Cutting Edge: IL-17-Secreting Innate Lymphoid Cells Are Essential for Host Defense against Fungal Infection. J. Immunol. 2012, 190, 521-525. [CrossRef]

29. Luu, M.; Steinhoff, U.; Visekruna, A. Functional heterogeneity of gut-resident regulatory T cells. Clin. Transl. Immunol. 2017, 6, e156. [CrossRef]

30. Goto, Y.; Obata, T.; Kunisawa, J.; Sato, S.; Ivanov, I.I.; Lamichhane, A.; Takeyama, N.; Kamioka, M.; Sakamoto, M.; Matsuki, T.; et al. Innate lymphoid cells regulate intestinal epithelial cell glycosylation. Science 2014, 345, 1254009. [CrossRef]

31. Sabihi, M.; Böttcher, M.; Pelczar, P.; Huber, S. Microbiota-Dependent Effects of IL-22. Cells 2020, 9, 2205. [CrossRef] [PubMed]

32. Levy, M.; Kolodziejczyk, A.A.; Thaiss, C.A.; Elinav, E. Dysbiosis and the immune system. Nat. Rev. Immunol. 2017, 17, 219-232. [CrossRef] [PubMed]

33. Thaiss, C.A.; Levy, M.; Suez, J.; Elinav, E. The interplay between the innate immune system and the microbiota. Curr. Opin. Immunol. 2014, 26, 41-48. [CrossRef] [PubMed]

34. Frantz, A.L.; Rogier, E.W.; Weber, C.R.; Shen, L.; Cohen, D.A.; Fenton, L.A.; Bruno, M.E.C.; Kaetzel, C.S. Targeted deletion of MyD88 in intestinal epithelial cells results in compromised antibacterial immunity associated with downregulation of polymeric immunoglobulin receptor, mucin-2, and antibacterial peptides. Mucosal Immunol. 2012, 5, 501-512. [CrossRef] [PubMed]

35. Bouskra, D.; Brézillon, C.; Bérard, M.; Werts, C.; Varona, R.; Boneca, I.G.; Eberl, G. Lymphoid tissue genesis induced by commensals through NOD1 regulates intestinal homeostasis. Nature 2008, 456, 507-510. [CrossRef]

36. Henao-Mejia, J.; Elinav, E.; Thaiss, C.A.; Flavell, R.A. Inflammasomes and Metabolic Disease. Annu. Rev. Physiol. 2014, 76, 57-78. [CrossRef] [PubMed]

37. Elinav, E.; Strowig, T.; Kau, A.L.; Henao-Mejia, J.; Thaiss, C.A.; Booth, C.J.; Peaper, D.R.; Bertin, J.; Eisenbarth, S.C.; Gordon, J.I.; et al. NLRP6 Inflammasome Regulates Colonic Microbial Ecology and Risk for Colitis. Cell 2011, 145, 745-757. [CrossRef]

38. Ghimire, L.; Paudel, S.; Jin, L.; Jeyaseelan, S. The NLRP6 inflammasome in health and disease. Mucosal Immunol. 2020, 13, 388-398. [CrossRef]

39. Belkaid, Y.; Hand, T.W. Role of the Microbiota in Immunity and Inflammation. Cell 2014, 157, 121-141. [CrossRef]

40. Raupach, B.; Peuschel, S.K.; Monack, D.M.; Zychlinsky, A. Caspase-1-mediated activation of interleukin-1beta (IL-1beta) and IL-18 contributes to innate immune defenses against Salmonella enterica serovar Typhimurium infection. Infect. Immun. 2006, 74, 4922-4926. [CrossRef]

41. Jarret, A.; Jackson, R.; Duizer, C.; Healy, M.E.; Zhao, J.; Rone, J.M.; Bielecki, P.; Sefik, E.; Roulis, M.; Rice, T.; et al. Enteric Nervous System-Derived IL-18 Orchestrates Mucosal Barrier Immunity. Cell 2020, 180, 813-814. [CrossRef] [PubMed]

42. Beck, K.; Ohno, H.; Satoh-Takayama, N. Innate Lymphoid Cells: Important Regulators of Host-Bacteria Interaction for Border Defense. Microorganisms 2020, 8, 1342. [CrossRef] [PubMed]

43. Yin, S.; Yu, J.; Hu, B.; Lu, C.; Liu, X.; Gao, X.; Li, W.; Zhou, L.; Wang, J.; Wang, D.; et al. Runx3 Mediates Resistance to Intracellular Bacterial Infection by Promoting IL12 Signaling in Group 1 ILC and NCR+ILC3. Front. Immunol. 2018, 9, 2101. [CrossRef] [PubMed]

44. Brown, E.M.; Kenny, D.J.; Xavier, R.J. Gut Microbiota Regulation of T Cells During Inflammation and Autoimmunity. Annu. Rev. Immunol. 2019, 37, 599-624. [CrossRef] [PubMed]

45. Reid-Yu, S.A.; Small, C.-L.N.; Coombes, B.K. CD3-NK1.1+cells aid in the early induction of a Th1 response to an attaching and effacing enteric pathogen. Eur. J. Immunol. 2013, 43, 2638-2649. [CrossRef]

46. Qiu, J.; Heller, J.J.; Guo, X.; Chen, Z.-M.E.; Fish, K.; Fu, Y.-X.; Zhou, L. The Aryl Hydrocarbon Receptor Regulates Gut Immunity through Modulation of Innate Lymphoid Cells. Immunity 2012, 36, 92-104. [CrossRef]

47. Kiss, E.A.; Vonarbourg, C.; Kopfmann, S.; Hobeika, E.; Finke, D.; Esser, C.; Diefenbach, A. Natural Aryl Hydrocarbon Receptor Ligands Control Organogenesis of Intestinal Lymphoid Follicles. Science 2011, 334, 1561-1565. [CrossRef]

48. Chen, J.; Waddell, A.E.; Lin, Y.-D.; Cantorna, M.T. Dysbiosis caused by vitamin D receptor deficiency confers colonization resistance to Citrobacter rodentium through modulation of innate lymphoid cells. Mucosal Immunol. 2015, 8, 618-626. [CrossRef] 
49. Yang, W.; Yu, T.; Huang, X.; Bilotta, A.J.; Xu, L.; Lu, Y.; Sun, J.; Pan, F.; Zhou, J.; Zhang, W.; et al. Intestinal microbiota-derived short-chain fatty acids regulation of immune cell IL-22 production and gut immunity. Nat. Commun. 2020, 11, 4457. [CrossRef]

50. Manta, C.; Heupel, E.; Radulovic, K.; Rossini, V.; Garbi, N.; Riedel, C.U.; Niess, J.H. CX3CR1+ macrophages support IL-22 production by innate lymphoid cells during infection with Citrobacter rodentium. Mucosal Immunol. 2012, 6, 177-188. [CrossRef]

51. Satoh-Takayama, N.; Serafini, N.; Verrier, T.; Rekiki, A.; Renauld, J.-C.; Frankel, G.; Di Santo, J.P. The Chemokine Receptor CXCR6 Controls the Functional Topography of Interleukin-22 Producing Intestinal Innate Lymphoid Cells. Immunity 2014, 41, 776-788. [CrossRef] [PubMed]

52. Longman, R.S.; Diehl, G.E.; Victorio, D.A.; Huh, J.R.; Galan, C.; Miraldi, E.R.; Swaminath, A.; Bonneau, R.; Scherl, E.J.; Littman, D.R. CX3CR1+ mononuclear phagocytes support colitis-associated innate lymphoid cell production of IL-22. J. Exp. Med. 2014, 211, 1571-1583. [CrossRef] [PubMed]

53. Bauché, D.; Joyce-Shaikh, B.; Fong, J.; Villarino, A.V.; Ku, K.S.; Jain, R.; Lee, Y.-C.; Annamalai, L.; Yearley, J.H.; Cua, D.J. IL-23 and IL-2 activation of STAT5 is required for optimal IL-22 production in ILC3s during colitis. Sci. Immunol. 2020, 5, eaav1080. [CrossRef] [PubMed]

54. Buzzelli, J.N.; Chalinor, H.V.; Pavlic, D.I.; Sutton, P.; Menheniott, T.R.; Giraud, A.S.; Judd, L.M. IL33 Is a Stomach Alarmin That Initiates a Skewed Th2 Response to Injury and Infection. Cell. Mol. Gastroenterol. Hepatol. 2015, 1, 203-221.e3. [CrossRef]

55. Satoh-Takayama, N.; Kato, T.; Motomura, Y.; Kageyama, T.; Taguchi-Atarashi, N.; Kinoshita-Daitoku, R.; Kuroda, E.; Di Santo, J.P.; Mimuro, H.; Moro, K.; et al. Bacteria-Induced Group 2 Innate Lymphoid Cells in the Stomach Provide Immune Protection through Induction of IgA. Immunity 2020, 52, 635-649.e4. [CrossRef]

56. Li, R.; Jiang, X.-X.; Zhang, L.-F.; Liu, X.-M.; Hu, T.-Z.; Xia, X.-J.; Li, M.; Xu, C.-X. Group 2 Innate Lymphoid Cells Are Involved in Skewed Type 2 Immunity of Gastric Diseases Induced by Helicobacter pylori Infection. Mediat. Inflamm. 2017, $2017,4927964$. [CrossRef]

57. Conteduca, V.; Sansonno, D.; Lauletta, G.; Russi, S.; Ingravallo, G.; Dammacco, F.H. pylori infection and gastric cancer: State of the art (review). Int. J. Oncol. 2013, 42, 5-18. [CrossRef]

58. Sonoyama, K.; Miki, A.; Sugita, R.; Goto, H.; Nakata, M.; Yamaguchi, N. Gut colonization by Candida albicans aggravates inflammation in the gut and extra-gut tissues in mice. Med. Mycol. 2011, 49, 237-247. [CrossRef]

59. Renga, G.; Moretti, S.; Oikonomou, V.; Borghi, M.; Zelante, T.; Paolicelli, G.; Costantini, C.; De Zuani, M.; Villella, V.R.; Raia, V.; et al. IL-9 and Mast Cells Are Key Players of Candida albicans Commensalism and Pathogenesis in the Gut. Cell Rep. 2018, 23, 1767-1778. [CrossRef]

60. Li, Q.; Wang, C.; Tang, C.; He, Q.; Li, N.; Li, J. Dysbiosis of Gut Fungal Microbiota is Associated With Mucosal Inflammation in Crohn's Disease. J. Clin. Gastroenterol. 2014, 48, 513-523. [CrossRef]

61. Perry, A.K.; Chen, G.; Zheng, D.; Tang, H.; Cheng, G. The host type I interferon response to viral and bacterial infections. Cell Res. 2005, 15, 407-422. [CrossRef] [PubMed]

62. Boshuizen, J.A.; Reimerink, J.; Male, A.M.K.-V.; Van Ham, V.J.J.; Koopmans, M.P.G.; Büller, H.A.; Dekker, J.; Einerhand, A.W.C. Changes in small intestinal homeostasis, morphology, and gene expression during rotavirus infection of infant mice. J. Virol. 2003, 77, 13005-13016. [CrossRef] [PubMed]

63. Baldridge, M.T.; Lee, S.; Brown, J.J.; McAllister, N.; Urbanek, K.; Dermody, T.S.; Nice, T.J.; Virgin, H.W. Expression of Ifnlr1 on Intestinal Epithelial Cells Is Critical to the Antiviral Effects of Interferon Lambda against Norovirus and Reovirus. J. Virol. 2017, 91. [CrossRef] [PubMed]

64. Pott, J.; Mahlakõiv, T.; Mordstein, M.; Duerr, C.U.; Michiels, T.; Stockinger, S.; Staeheli, P.; Hornef, M.W. IFN-lambda determines the intestinal epithelial antiviral host defense. Proc. Natl. Acad. Sci. USA 2011, 108, 7944-7949. [CrossRef]

65. Villena, J.; Vizoso-Pinto, M.G.; Kitazawa, H. Intestinal Innate Antiviral Immunity and Immunobiotics: Beneficial Effects against Rotavirus Infection. Front. Immunol. 2016, 7, 563. [CrossRef]

66. Clayburgh, D.R.; Shen, L.; Turner, J.R. A porous defense: The leaky epithelial barrier in intestinal disease. Lab. Investig. 2004, 84, 282-291. [CrossRef]

67. Chatila, R.; Merhi, M.; Hariri, E.; Sabbah, N.; Deeb, M.E. Irritable bowel syndrome: Prevalence, risk factors in an adult Lebanese population. BMC Gastroenterol. 2017, 17, 137. [CrossRef]

68. Lazaridis, N.; Germanidis, G. Current insights into the innate immune system dysfunction in irritable bowel syndrome. Ann. Gastroenterol. 2018, 31, 171-187. [CrossRef]

69. O'Mahony, L.; McCarthy, J.; Kelly, P.; Hurley, G.; Luo, F.; Chen, K.; O’Sullivan, G.C.; Kiely, B.; Collins, J.K.; Shanahan, F.; et al. Lactobacillus and bifidobacterium in irritable bowel syndrome: Symptom responses and relationship to cytokine profiles. Gastroenterology 2005, 128, 541-551. [CrossRef]

70. Zhen, Y.; Chu, C.; Zhou, S.; Qi, M.; Shu, R. Imbalance of tumor necrosis factor-?, interleukin-8 and interleukin-10 production evokes barrier dysfunction, severe abdominal symptoms and psychological disorders in patients with irritable bowel syndromeassociated diarrhea. Mol. Med. Rep. 2015, 12, 5239-5245. [CrossRef]

71. Liebregts, T.; Adam, B.; Bredack, C.; Röth, A.; Heinzel, S.; Lester, S.; Downie-Doyle, S.; Smith, E.; Drew, P.; Talley, N.J.; et al. Immune Activation in Patients With Irritable Bowel Syndrome. Gastroenterology 2007, 132, 913-920. [CrossRef] [PubMed]

72. Del Valle-Pinero, A.Y.; Martino, A.C.; Taylor, T.J.; Majors, B.L.; Patel, N.S.; Heitkemper, M.M.; Henderson, W.A. Pro-inflammatory chemokine C-C motif ligand 16 (CCL-16) dysregulation in irritable bowel syndrome (IBS): A pilot study. Neurogastroenterol. Motil. 2011, 23, 1092-1097. [CrossRef] [PubMed] 
73. Tülübaş, F.; Oran, M.; Mete, R.; Turan, F.; Yilmaz, A.; Yildiz, Z.D.; Gürel, A. Investigation of serum macrophage migration inhibitor factor and monocyte chemotactic protein-1 levels in irritable bowel syndrome. Turk. J. Med Sci. 2014, 44, 967-971. [CrossRef]

74. Barkhordari, E.; Rezaei, N.; Ansaripour, B.; Larki, P.; Alighardashi, M.; Ahmadi-Ashtiani, H.R.; Mahmoudi, M.; Keramati, M.R.; Habibollahi, P.; Bashashati, M.; et al. Proinflammatory Cytokine Gene Polymorphisms in Irritable Bowel Syndrome. J. Clin. Immunol. 2009, 30, 74-79. [CrossRef] [PubMed]

75. Villani, A.; Lemire, M.; Thabane, M.; Belisle, A.; Geneau, G.; Garg, A.X.; Clark, W.F.; Moayyedi, P.; Collins, S.M.; Franchimont, D.; et al. Genetic Risk Factors for Post-Infectious Irritable Bowel Syndrome Following a Waterborne Outbreak of Gastroenteritis. Gastroenterology 2010, 138, 1502-1513. [CrossRef]

76. Dunne, M.R.; Byrne, G.; Chirdo, F.G.; Feighery, C. Coeliac Disease Pathogenesis: The Uncertainties of a Well-Known Immune Mediated Disorder. Front. Immunol. 2020, 11, 1374. [CrossRef]

77. Di Sabatino, A. Epithelium derived interleukin 15 regulates intraepithelial lymphocyte Th1 cytokine production, cytotoxicity, and survival in coeliac disease. Gut 2006, 55, 469-477. [CrossRef]

78. Drago, S.; El Asmar, R.; Di Pierro, M.; Clemente, M.G.; Sapone, A.T.A.; Thakar, M.; Iacono, G.; Carroccio, A.; D’Agate, C.; Not, T.; et al. Gliadin, zonulin and gut permeability: Effects on celiac and non-celiac intestinal mucosa and intestinal cell lines. Scand. J. Gastroenterol. 2006, 41, 408-419. [CrossRef]

79. Matysiak-Budnik, T.; Candalh, C.; Dugave, C.; Namane, A.; Cellier, C.; Cerf-Bensussan, N.; Heyman, M. Alterations of the intestinal transport and processing of gliadin peptides in celiac disease. Gastroenterology 2003, 125, 696-707. [CrossRef]

80. Clemente, M.G.; De Virgiliis, S.; Kang, J.S.; Macatagney, R.; Musu, M.P.; Di Pierro, M.R.; Drago, S.; Congia, M.; Fasano, A. Early effects of gliadin on enterocyte intracellular signalling involved in intestinal barrier function. Gut 2003, 52, 218-223. [CrossRef]

81. Meresse, B.; Chen, Z.; Ciszewski, C.; Tretiakova, M.; Bhagat, G.; Krausz, T.N.; Raulet, D.H.; Lanier, L.L.; Groh, V.; Spies, T.; et al Coordinated Induction by IL15 of a TCR-Independent NKG2D Signaling Pathway Converts CTL into Lymphokine-Activated Killer Cells in Celiac Disease. Immunity 2004, 21, 357-366. [CrossRef] [PubMed]

82. Abadie, V.; Jabri, B. IL-15: A central regulator of celiac disease immunopathology. Immunol. Rev. 2014, 260, 221-234. [CrossRef] [PubMed]

83. Dieterich, W.; Ehnis, T.; Bauer, M.; Donner, P.; Volta, U.; Riecken, E.O.; Schuppan, D. Identification of tissue transglutaminase as the autoantigen of celiac disease. Nat. Med. 1997, 3, 797-801. [CrossRef] [PubMed]

84. Garrote, J.A.; Gómez-González, E.; Bernardo, D.; Arranz, E.; Chirdo, F. Celiac Disease Pathogenesis: The Proinflammatory Cytokine Network. J. Pediatr. Gastroenterol. Nutr. 2008, 47, S27-S32. [CrossRef] [PubMed]

85. Pickert, G.; Wirtz, S.; Matzner, J.; Ashfaq-Khan, M.; Heck, R.; Rosigkeit, S.; Thies, D.; Surabattula, R.; Ehmann, D.; Wehkamp, J.; et al. Wheat Consumption Aggravates Colitis in Mice via Amylase Trypsin Inhibitor-mediated Dysbiosis. Gastroenterology 2020, 159, 257-272.e17. [CrossRef] [PubMed]

86. Marotto, D.; Atzeni, F.; Ardizzone, S.; Monteleone, G.; Giorgi, V.; Sarzi-Puttini, P. Extra-intestinal manifestations of inflammatory bowel diseases. Pharmacol. Res. 2020, 161, 105206. [CrossRef]

87. Marafini, I.; Sedda, S.; DiNallo, V.; Monteleone, G. Inflammatory cytokines: From discoveries to therapies in IBD. Expert Opin. Biol. Ther. 2019, 19, 1207-1217. [CrossRef]

88. de Souza, H.S.; Fiocchi, C. Immunopathogenesis of IBD: Current state of the art. Nat. Rev. Gastroenterol. Hepatol. 2016, 13, 13-27. [CrossRef]

89. Neurath, M.F. IL-23 in inflammatory bowel diseases and colon cancer. Cytokine Growth Factor Rev. 2019, 45, 1-8. [CrossRef]

90. Gately, M.K.; Renzetti, L.M.; Magram, J.; Stern, A.S.; Adorini, L.; Gubler, U.; Presky, D.H. The interleukin-12/interleukin-12receptor system: Role in Normal and Pathologic Immune Responses. Annu. Rev. Immunol. 1998, 16, 495-521. [CrossRef]

91. Langrish, C.L.; McKenzie, B.S.; Wilson, N.J.; Malefyt, R.D.W.; Kastelein, R.A.; Cua, D.J. IL-12 and IL-23: Master regulators of innate and adaptive immunity. Immunol. Rev. 2004, 202, 96-105. [CrossRef] [PubMed]

92. Andrews, C.; McLean, M.H.; Durum, S.K. Interleukin-27 as a Novel Therapy for Inflammatory Bowel Disease: A Critical Review of the Literature. Inflamm. Bowel Dis. 2016, 22, 2255-2264. [CrossRef] [PubMed]

93. Sasaoka, T.; Ito, M.; Yamashita, J.; Nakajima, K.; Tanaka, I.; Narita, M.; Hara, Y.; Hada, K.; Takahashi, M.; Ohno, Y.; et al. Treatment with IL-27 attenuates experimental colitis through the suppression of the development of IL-17-producing T helper cells. Am. J. Physiol. Liver Physiol. 2011, 300, G568-G576. [CrossRef] [PubMed]

94. Hanson, M.L.; Hixon, J.A.; Li, W.; Felber, B.K.; Anver, M.R.; Stewart, C.A.; Janelsins, B.M.; Datta, S.K.; Shen, W.; McLean, M.H.; et al. Oral Delivery of IL-27 Recombinant Bacteria Attenuates Immune Colitis in Mice. Gastroenterology 2014, 146, 210-221.e13. [CrossRef] [PubMed]

95. Cox, J.H.; Kljavin, N.M.; Ramamoorthi, N.; Diehl, L.; Batten, M.; Ghilardi, N. IL-27 promotes T cell-dependent colitis through multiple mechanisms. J. Exp. Med. 2010, 208, 115-123. [CrossRef]

96. Neurath, M.F. Cytokines in inflammatory bowel disease. Nat. Rev. Immunol. 2014, 14, 329-342. [CrossRef]

97. Atreya, R.; Zimmer, M.; Bartsch, B.; Waldner, M.; Atreya, I.; Neumann, H.; Hildner, K.; Hoffman, A.; Kiesslich, R.; Rink, A.D.; et al. Antibodies Against Tumor Necrosis Factor (TNF) Induce T-Cell Apoptosis in Patients With Inflammatory Bowel Diseases via TNF Receptor 2 and Intestinal CD14+ Macrophages. Gastroenterology 2011, 141, 2026-2038. [CrossRef] 
98. Kamada, N.; Hisamatsu, T.; Okamoto, S.; Chinen, H.; Kobayashi, T.; Sato, T.; Sakuraba, A.; Kitazume, M.T.; Sugita, A.; Koganei, K.; et al. Unique CD14+ intestinal macrophages contribute to the pathogenesis of Crohn disease via IL-23/IFN- $\gamma$ axis. J. Clin. Investig. 2008, 118, 2269-2280. [CrossRef]

99. Günther, C.; Martini, E.; Wittkopf, N.; Amann, K.; Weigmann, B.; Neumann, H.; Waldner, M.J.; Hedrick, S.M.; Tenzer, S.; Neurath, M.F.; et al. Caspase-8 regulates TNF- $\alpha$-induced epithelial necroptosis and terminal ileitis. Nature 2011, 477, 335-339. [CrossRef]

100. Su, L.; Nalle, S.C.; Shen, L.; Turner, E.S.; Singh, G.; Breskin, L.A.; Khramtsova, E.A.; Khramtsova, G.; Tsai, P.; Fu, Y.; et al. TNFR2 Activates MLCK-Dependent Tight Junction Dysregulation to Cause Apoptosis-Mediated Barrier Loss and Experimental Colitis. Gastroenterology 2013, 145, 407-415. [CrossRef]

101. Monteleone, G.; Caruso, R.; Fina, D.; Peluso, I.; Gioia, V.; Stolfi, C.; Fantini, M.C.; Caprioli, F.; Tersigni, R.; Alessandroni, L.; et al. Control of matrix metalloproteinase production in human intestinal fibroblasts by interleukin 21. Gut 2006, 55, 1774-1780. [CrossRef] [PubMed]

102. Monteleone, G.; Monteleone, I.; Fina, D.; Vavassori, P.; Blanco, G.D.V.; Caruso, R.; Tersigni, R.; Alessandroni, L.; Biancone, L.; Naccari, G.C.; et al. Interleukin-21 enhances T-helper cell type I signaling and interferon-gamma production in Crohn's disease. Gastroenterology 2005, 128, 687-694. [CrossRef] [PubMed]

103. Siakavellas, S.I.; Bamias, G. Role of the IL-23/IL-17 axis in Crohn's disease. Discov. Med. 2012, 14, 253-262. [PubMed]

104. Pickert, G.; Neufert, C.; Leppkes, M.; Zheng, Y.; Wittkopf, N.; Warntjen, M.; Lehr, H.-A.; Hirth, S.; Weigmann, B.; Wirtz, S.; et al. STAT3 links IL-22 signaling in intestinal epithelial cells to mucosal wound healing. J. Exp. Med. 2009, 206, 1465-1472. [CrossRef]

105. Zenewicz, L.A.; Yancopoulos, G.D.; Valenzuela, D.M.; Murphy, A.J.; Stevens, S.; Flavell, R.A. Innate and Adaptive Interleukin-22 Protects Mice from Inflammatory Bowel Disease. Immunity 2008, 29, 947-957. [CrossRef]

106. Latiano, A.; Palmieri, O.; Pastorelli, L.; Vecchi, M.; Pizarro, T.T.; Bossa, F.; Merla, G.; Augello, B.; Latiano, T.; Corritore, G.; et al. Associations between Genetic Polymorphisms in IL-33, IL1R1 and Risk for Inflammatory Bowel Disease. PLoS ONE 2013, 8, e62144. [CrossRef]

107. Pastorelli, L.; De Salvo, C.; Vecchi, M.; Pizarro, T.T. The Role of IL-33 in Gut Mucosal Inflammation. Mediat. Inflamm. 2013, $2013,608187$. [CrossRef]

108. Guan, Q.; Zhang, J. Recent Advances: The Imbalance of Cytokines in the Pathogenesis of Inflammatory Bowel Disease. Mediat. Inflamm. 2017, 2017, 4810258. [CrossRef]

109. Sedhom, M.A.K.; Pichery, M.; Murdoch, J.R.; Foligné, B.; Ortega, N.; Normand, S.; Mertz, K.D.; Sanmugalingam, D.; Brault, L.; Grandjean, T.; et al. Neutralisation of the interleukin-33/ST2 pathway ameliorates experimental colitis through enhancement of mucosal healing in mice. Gut 2012, 62, 1714-1723. [CrossRef]

110. Zhu, J.; Yang, F.; Sang, L.; Zhai, J.; Zhang, X.; Yue, D.; Li, S.; Li, Y.; Lu, C.; Sun, X. IL-33 Aggravates DSS-Induced Acute Colitis in Mouse Colon Lamina Propria by Enhancing Th2 Cell Responses. Mediat. Inflamm. 2015, 2015, 913041. [CrossRef]

111. Pushparaj, P.N.; Li, D.; Komai-Koma, M.; Guabiraba, R.; Alexander, J.; McSharry, C.; Xu, D. Interleukin-33 exacerbates acute colitis via interleukin-4 in mice. Immunology 2013, 140, 70-77. [CrossRef] [PubMed]

112. Zhu, J.; Wang, Y.; Yang, F.; Sang, L.; Zhai, J.; Li, S.; Li, Y.; Wang, D.; Lu, C.-L.; Sun, X. IL-33 alleviates DSS-induced chronic colitis in C57BL/ 6 mice colon lamina propria by suppressing Th17 cell response as well as Th1 cell response. Int. Immunopharmacol. 2015, 29, 846-853. [CrossRef] [PubMed]

113. Duan, L.; Chen, J.; Zhang, H.; Yang, H.; Zhu, P.; Xiong, A.; Xia, Q.; Zheng, F.; Tan, Z.; Gong, F.; et al. Interleukin-33 Ameliorates Experimental Colitis through Promoting Th2/Foxp3+ Regulatory T-Cell Responses in Mice. Mol. Med. 2012, 18, 753-761. [CrossRef] [PubMed]

114. Monticelli, L.A.; Osborne, L.C.; Noti, M.; Tran, S.V.; Zaiss, D.M.; Artis, D. IL-33 promotes an innate immune pathway of intestinal tissue protection dependent on amphiregulin-EGFR interactions. Proc. Natl. Acad. Sci. USA 2015, 112, 10762-10767. [CrossRef] [PubMed]

115. West, N.R.; Oxford IBD Cohort Investigators; Hegazy, A.N.; Owens, B.M.J.; Bullers, S.J.; Linggi, B.; Buonocore, S.; Coccia, M.; Görtz, D.; This, S.; et al. Oncostatin M drives intestinal inflammation and predicts response to tumor necrosis factor-neutralizing therapy in patients with inflammatory bowel disease. Nat. Med. 2017, 23, 579-589. [CrossRef] [PubMed]

116. Kim, W.M.; Kaser, A.; Blumberg, R.S. A role for oncostatin M in inflammatory bowel disease. Nat. Med. 2017, 23, 535-536. [CrossRef]

117. Beigel, F.; Friedrich, M.; Probst, C.; Sotlar, K.; Göke, B.; Diegelmann, J.; Brand, S. Oncostatin M Mediates STAT3-Dependent Intestinal Epithelial Restitution via Increased Cell Proliferation, Decreased Apoptosis and Upregulation of SERPIN Family Members. PLoS ONE 2014, 9, e93498. [CrossRef]

118. Quirós, M.; Nishio, H.; Neumann, P.A.; Siuda, D.; Brazil, J.C.; Azcutia, V.; Hilgarth, R.; O’Leary, M.N.; Garcia-Hernandez, V.; Leoni, G.; et al. Macrophage-derived IL-10 mediates mucosal repair by epithelial WISP-1 signaling. J. Clin. Investig. 2017, 127, 3510-3520. [CrossRef]

119. Wei, H.-X.; Wang, B.; Li, B. IL-10 and IL-22 in Mucosal Immunity: Driving Protection and Pathology. Front. Immunol. 2020, 11, 1315. [CrossRef]

120. Leman, J.K.H.; Munoz-Erazo, L.; Kemp, R.A. The Intestinal Tumour Microenvironment. Cannabinoids Neuropsychiatr. Disord. 2020, 1226, 1-22. [CrossRef] 
121. Li, J.; Huang, L.; Zhao, H.; Yan, Y.; Lu, J. The Role of Interleukins in Colorectal Cancer. Int. J. Biol. Sci. 2020, 16, $2323-2339$. [CrossRef] [PubMed]

122. Mager, L.F.; Wasmer, M.H.; Rau, T.T.; Krebs, P. Cytokine-Induced Modulation of Colorectal Cancer. Front. Oncol. 2016, 6, 96. [CrossRef] [PubMed]

123. Koller, F.L.; Hwang, D.G.; Dozier, E.; Fingleton, B. Epithelial interleukin-4 receptor expression promotes colon tumor growth. Carcinogenesis 2010, 31, 1010-1017. [CrossRef] [PubMed]

124. Tosolini, M.; Kirilovsky, A.; Mlecnik, B.; Fredriksen, T.; Mauger, S.; Bindea, G.; Berger, A.; Bruneval, P.; Fridman, W.-H.; Pagès, F.; et al. Clinical Impact of Different Classes of Infiltrating T Cytotoxic and Helper Cells (Th1, Th2, Treg, Th17) in Patients with Colorectal Cancer. Cancer Res. 2011, 71, 1263-1271. [CrossRef]

125. Sarrabayrouse, G.; Corvaisier, M.; Ouisse, L.-H.; Bossard, C.; Le Mével, B.; Potiron, L.; Meurette, G.; Gervois, N.; Jotereau, F. Tumor-reactive CD4+CD8 $\alpha \beta+\mathrm{CD} 103+\alpha \beta$ T cells: A prevalent tumor-reactive T-cell subset in metastatic colorectal cancers. Int. J. Cancer 2011, 128, 2923-2932. [CrossRef]

126. Ingram, N.; Northwood, E.L.; Perry, S.L.; Marston, G.; Snowden, H.; Taylor, J.C.; Scott, N.; Bishop, D.T.; Coletta, P.L.; Hull, M.A. Reduced type II interleukin-4 receptor signalling drives initiation, but not progression, of colorectal carcinogenesis: Evidence from transgenic mouse models and human case-control epidemiological observations. Carcinogenesis 2013, 34, 2341-2349. [CrossRef]

127. Nelms, K.; Keegan, A.D.; Zamorano, J.; Ryan, J.J.; Paul, W.E. THE IL-4 RECEPTOR: Signaling Mechanisms and Biologic Functions. Annu. Rev. Immunol. 1999, 17, 701-738. [CrossRef]

128. Wang, C.-G.; Ye, Y.-J.; Yuan, J.; Liu, F.-F.; Zhang, H.; Wang, S. EZH2 and STAT6 expression profiles are correlated with colorectal cancer stage and prognosis. World J. Gastroenterol. 2010, 16, 2421-2427. [CrossRef]

129. Kantola, T.; Klintrup, K.; Väyrynen, J.P.; Vornanen, J.; Bloigu, R.; Karhu, T.; Herzig, K.-H.; Näpänkangas, J.; Mäkelä, J.; Karttunen, T.J.; et al. Stage-dependent alterations of the serum cytokine pattern in colorectal carcinoma. Br. J. Cancer 2012, 107, 1729-1736. [CrossRef]

130. Becker, C.; Fantini, M.; Schramm, C.; Lehr, H.; Wirtz, S.; Burg, J.; Strand, S.; Kiesslich, R.; Huber, S.; Galle, P.; et al. TGFbeta suppresses tumor progression in colon cancer by inhibition of IL-6 trans-signaling. Zeitschrift für Gastroenterologie 2004, 42, 491-501. [CrossRef]

131. Atreya, R.; Mudter, J.; Finotto, S.; Müllberg, J.; Jostock, T.; Wirtz, S.; Schütz, M.; Bartsch, B.; Holtmann, M.; Becker, C.; et al. Blockade of interleukin 6 trans signaling suppresses T-cell resistance against apoptosis in chronic intestinal inflammation: Evidence in Crohn disease and experimental colitis in vivo. Nat. Med. 2000, 6, 583-588. [CrossRef]

132. Kusaba, T.; Nakayama, T.; Yamazumi, K.; Yakata, Y.; Yoshizaki, A.; Inoue, K.; Nagayasu, T.; Sekine, I. Activation of STAT3 is a marker of poor prognosis in human colorectal cancer. Oncol. Rep. 2006, 15, 1445-1451. [CrossRef] [PubMed]

133. Ljujic, B.; Radosavljevic, G.; Jovanovic, I.P.; Pavlovic, S.; Zdravkovic, N.; Milovanovic, M.; Acimovic, L.; Knežević, M.; Banković, D.; Zdravkovic, D.; et al. Elevated Serum Level of IL-23 Correlates with Expression of VEGF in Human Colorectal Carcinoma. Arch. Med Res. 2010, 41, 182-189. [CrossRef] [PubMed]

134. Langowski, J.L.; Zhang, X.; Wu, L.; Mattson, J.D.; Chen, T.; Smith, K.; Basham, B.; McClanahan, T.; Kastelein, R.A.; Oft, M. IL-23 promotes tumour incidence and growth. Nature 2006, 442, 461-465. [CrossRef] [PubMed]

135. Hue, S.; Ahern, P.; Buonocore, S.; Kullberg, M.C.; Cua, D.J.; McKenzie, B.S.; Powrie, F.; Maloy, K.J. Interleukin-23 drives innate and T cell-mediated intestinal inflammation. J. Exp. Med. 2006, 203, 2473-2483. [CrossRef]

136. Yen, D.; Cheung, J.; Scheerens, H.; Poulet, F.; McClanahan, T.; McKenzie, B.; Kleinschek, M.A.; Owyang, A.; Mattson, J.; Blumenschein, W.; et al. IL-23 is essential for T cell-mediated colitis and promotes inflammation via IL-17 and IL-6. J. Clin. Investig. 2006, 116, 1310-1316. [CrossRef] [PubMed]

137. Khare, V.; Paul, G.; Movadat, O.; Frick, A.; Jambrich, M.; Krnjic, A.; Marian, B.; Wrba, F.; Gasche, C. IL10R2 Overexpression Promotes IL22/STAT3 Signaling in Colorectal Carcinogenesis. Cancer Immunol. Res. 2015, 3, 1227-1235. [CrossRef]

138. Zhang, L.; Li, J.; Li, L.; Zhang, J.; Wang, X.; Yang, C.; Li, Y.; Lan, F.; Lin, P. IL-23 selectively promotes the metastasis of colorectal carcinoma cells with impaired Socs3 expression via the STAT5 pathway. Carcinogenesis 2014, 35, 1330-1340. [CrossRef]

139. Gronke, K.; Hernández, P.P.; Zimmermann, J.; Klose, C.S.N.; Kofoed-Branzk, M.; Guendel, F.; Witkowski, M.; Tizian, C.; Amann, L.; Schumacher, F.; et al. Interleukin-22 protects intestinal stem cells against genotoxic stress. Nature 2019, 566, 249-253. [CrossRef]

140. Kryczek, I.; Lin, Y.; Nagarsheth, N.; Peng, D.; Zhao, L.; Zhao, E.; Vatan, L.; Szeliga, W.; Dou, Y.; Owens, S.; et al. IL-22+CD4+ T Cells Promote Colorectal Cancer Stemness via STAT3 Transcription Factor Activation and Induction of the Methyltransferase DOT1L. Immunity 2014, 40, 772-784. [CrossRef]

141. Waldner, M.J.; Wirtz, S.; Jefremow, A.; Warntjen, M.; Neufert, C.; Atreya, R.; Becker, C.; Weigmann, B.; Vieth, M.; Rose-John, S.; et al. VEGF receptor signaling links inflammation and tumorigenesis in colitis-associated cancer. J. Exp. Med. 2010, 207, 2855-2868. [CrossRef] [PubMed]

142. Goodlad, R.A.; Ryan, A.; Wedge, S.; Pyrah, I.; Alferez, D.; Poulsom, R.; Smith, N.; Mandir, N.; Watkins, A.; Wilkinson, R.W. Inhibiting vascular endothelial growth factor receptor-2 signaling reduces tumor burden in the ApcMin/+ mouse model of early intestinal cancer. Carcinogenesis 2006, 27, 2133-2139. [CrossRef] [PubMed]

143. Easwaran, V.; Lee, S.H.; Inge, L.; Guo, L.; Goldbeck, C.; Garrett, E.; Wiesmann, M.; Garcia, P.D.; Fuller, J.H.; Chan, V.; et al. beta-Catenin regulates vascular endothelial growth factor expression in colon cancer. Cancer Res. 2003, 63, 3145-3153. [PubMed] 
144. Lakatos, P.L.; Lakatos, L. Risk for colorectal cancer in ulcerative colitis: Changes, causes and management strategies. World J. Gastroenterol. 2008, 14, 3937-3947. [CrossRef] [PubMed]

145. Kobelt, D.; Zhang, C.; Clayton-Lucey, I.A.; Glauben, R.; Voss, C.; Siegmund, B.; Stein, U. Pro-inflammatory TNF-alpha and IFN-gamma Promote Tumor Growth and Metastasis via Induction of MACC1. Front. Immunol. 2020, 11, 980. [CrossRef] [PubMed]

146. Balkwill, F.R. Tumour necrosis factor and cancer. Nat. Rev. Cancer 2009, 9, 361-371. [CrossRef] [PubMed]

147. Cox, G.W.; Melillo, G.; Chattopadhyay, U.; Mullet, D.; Fertel, R.H.; Varesio, L. Tumor necrosis factor-alpha-dependent production of reactive nitrogen intermediates mediates IFN-gamma plus IL-2-induced murine macrophage tumoricidal activity. J. Immunol. 1992, 149, 3290-3296.

148. Zins, K.; Abraham, D.; Sioud, M.; Aharinejad, S. Colon Cancer Cell-Derived Tumor Necrosis Factor- $\alpha$ Mediates the Tumor Growth-Promoting Response in Macrophages by Up-regulating the Colony-Stimulating Factor-1 Pathway. Cancer Res. 2007, 67, 1038-1045. [CrossRef]

149. Hamilton, K.E.; Simmons, J.G.; Ding, S.; Van Landeghem, L.; Lund, P.K. Cytokine Induction of Tumor Necrosis Factor Receptor 2 Is Mediated by STAT3 in Colon Cancer Cells. Mol. Cancer Res. 2011, 9, 1718-1731. [CrossRef]

150. Popivanova, B.K.; Kitamura, K.; Wu, Y.; Kondo, T.; Kagaya, T.; Kaneko, S.; Oshima, M.; Fujii, C.; Mukaida, N. Blocking TNF- $\alpha$ in mice reduces colorectal carcinogenesis associated with chronic colitis. J. Clin. Investig. 2008, 118, 560-570. [CrossRef]

151. Maywald, R.L.; Doerner, S.K.; Pastorelli, L.; De Salvo, C.; Benton, S.M.; Dawson, E.P.; Lanza, D.G.; Berger, N.A.; Markowitz, S.D.; Lenz, H.J.; et al. IL-33 activates tumor stroma to promote intestinal polyposis. Proc. Natl. Acad. Sci. USA 2015, 112, E2487-E2496. [CrossRef] [PubMed]

152. He, Z.; Chen, L.; Souto, F.O.; Canasto-Chibuque, C.; Bongers, G.; Deshpande, M.; Harpaz, N.; Ko, H.M.; Kelley, K.; Furtado, G.C.; et al. Epithelial-derived IL-33 promotes intestinal tumorigenesis in Apc Min/+ mice. Sci. Rep. 2017, 7, 5520. [CrossRef] [PubMed]

153. Larsen, K.M.; Minaya, M.K.; Vaish, V.; Peña, M.M.O. The Role of IL-33/ST2 Pathway in Tumorigenesis. Int. J. Mol. Sci. 2018, $19,2676$. [CrossRef] [PubMed]

154. Pastille, E.; Wasmer, M.-H.; Adamczyk, A.; Vu, V.P.; Mager, L.F.; Phuong, N.N.T.; Palmieri, V.; Simillion, C.; Hansen, W.; Kasper, S.; et al. The IL-33/ST2 pathway shapes the regulatory T cell phenotype to promote intestinal cancer. Mucosal Immunol. 2019, 12, 990-1003. [CrossRef]

155. Mahapatro, M.; Foersch, S.; Hefele, M.; He, G.-W.; Giner-Ventura, E.; Mchedlidze, T.; Kindermann, M.; Vetrano, S.; Danese, S.; Günther, C.; et al. Programming of Intestinal Epithelial Differentiation by IL-33 Derived from Pericryptal Fibroblasts in Response to Systemic Infection. Cell Rep. 2016, 15, 1743-1756. [CrossRef]

156. Waugh, D.J.; Wilson, C. The Interleukin-8 Pathway in Cancer. Clin. Cancer Res. 2008, 14, 6735-6741. [CrossRef]

157. Yoshizaki, A.; Nakayama, T.; Yamazumi, K.; Yakata, Y.; Taba, M.; Sekine, I. Expression of interleukin (IL)-11 and IL-11 receptor in human colorectal adenocarcinoma: IL-11 up-regulation of the invasive and proliferative activity of human colorectal carcinoma cells. Int. J. Oncol. 2006, 29, 869-876. [CrossRef]

158. Putoczki, T.L.; Thiem, S.; Loving, A.; Busuttil, R.A.; Wilson, N.J.; Ziegler, P.K.; Nguyen, P.M.; Preaudet, A.; Farid, R.; Edwards, K.M.; et al. Interleukin-11 Is the Dominant IL-6 Family Cytokine during Gastrointestinal Tumorigenesis and Can Be Targeted Therapeutically. Cancer Cell 2013, 24, 257-271. [CrossRef]

159. Evans, C.P.; Morrison, I.; Heriot, A.G.; Bartlett, J.B.; Finlayson, C.; Dalgleish, A.G.; Kumar, D. The correlation between colorectal cancer rates of proliferation and apoptosis and systemic cytokine levels; plus their influence upon survival. Br. J. Cancer 2006, 94, 1412-1419. [CrossRef]

160. Osawa, E.; Nakajima, A.; Fujisawa, T.; Kawamura, Y.I.; Toyama-Sorimachi, N.; Nakagama, H.; Dohi, T. Predominant T helper type 2-inflammatory responses promote murine colon cancers. Int. J. Cancer 2005, 118, 2232-2236. [CrossRef]

161. Wang, L.; Wang, Y.; Song, Z.; Chu, J.; Qu, X. Deficiency of Interferon-Gamma or Its Receptor Promotes Colorectal Cancer Development. J. Interf. Cytokine Res. 2015, 35, 273-280. [CrossRef] [PubMed]

162. Mishra, A.; Sullivan, L.; Caligiuri, M.A. Molecular Pathways: Interleukin-15 Signaling in Health and in Cancer. Clin. Cancer Res. 2014, 20, 2044-2050. [CrossRef] [PubMed]

163. Bahri, R.; Pateras, I.S.; D’Orlando, O.; Goyeneche-Patino, D.A.; Campbell, M.; Polansky, J.K.; Sandig, H.; Papaioannou, M.; Evangelou, K.; Foukas, P.G.; et al. IL-15 suppresses colitis-associated colon carcinogenesis by inducing antitumor immunity. OncoImmunology 2015, 4, e1002721. [CrossRef] [PubMed]

164. Jabri, B.; Abadie, V. IL-15 functions as a danger signal to regulate tissue-resident T cells and tissue destruction. Nat. Rev. Immunol. 2015, 15, 771-783. [CrossRef]

165. Fung, K.Y.; Nguyen, P.M.; Putoczki, T.L. Emerging Roles for Interleukin-18 in the Gastrointestinal Tumor Microenvironment. Optogenetics 2020, 1240, 59-72. [CrossRef]

166. Salcedo, R.; Worschech, A.; Cardone, M.; Jones, Y.; Gyulai, Z.; Dai, R.-M.; Wang, E.; Ma, W.; Haines, D.; O’Huigin, C.; et al. MyD88mediated signaling prevents development of adenocarcinomas of the colon: Role of interleukin 18. J. Exp. Med. 2010, 207, 1625-1636. [CrossRef]

167. Kunze, F.A.; Bauer, M.; Komuczki, J.; Lanzinger, M.; Gunasekera, K.; Hopp, A.K.; Lehmann, M.; Becher, B.; Müller, A.; Hottiger, M.O. ARTD1 in Myeloid Cells Controls the IL-12/18-IFN-gamma Axis in a Model of Sterile Sepsis, Chronic Bacterial Infection, and Cancer. J. Immunol. 2019, 202, 1406-1416. [CrossRef]

168. Tong, Z.; Yang, X.O.; Yan, H.; Liu, W.; Niu, X.; Shi, Y.; Fang, W.; Xiong, B.; Wan, Y.; Dong, C. A Protective Role by Interleukin-17F in Colon Tumorigenesis. PLoS ONE 2012, 7, e34959. [CrossRef] 
169. Razi, S.; Noveiry, B.B.; Keshavarz-Fathi, M.; Rezaei, N. IL-17 and colorectal cancer: From carcinogenesis to treatment. Cytokine 2019, 116, 7-12. [CrossRef]

170. Chen, Y.; Yang, Z.; Wu, D.; Min, Z.; Quan, Y. Upregulation of interleukin-17F in colorectal cancer promotes tumor invasion by inducing epithelial-mesenchymal transition. Oncol. Rep. 2019, 42, 1141-1148. [CrossRef]

171. Girondel, C.; Lévesque, K.; Langlois, M.-J.; Pasquin, S.; Saba-El-Leil, M.K.; Rivard, N.; Friesel, R.; Servant, M.J.; Gauchat, J.-F.; Lesage, S.; et al. Loss of interleukin-17 receptor D promotes chronic inflammation-associated tumorigenesis. Oncogene 2020, 1-13. [CrossRef] [PubMed]

172. Lin, C.-C.; Liao, T.-T.; Yang, M. Immune Adaptation of Colorectal Cancer Stem Cells and Their Interaction With the Tumor Microenvironment. Front. Oncol. 2020, 10, 588542. [CrossRef] [PubMed]

173. Czajka-Francuz, P.; Francuz, T.; Cisoń-Jurek, S.; Czajka, A.; Fajkis, M.; Szymczak, B.; Kozaczka, M.; Malinowski, K.P.; Zasada, W.; Wojnar, J.; et al. Serum cytokine profile as a potential prognostic tool in colorectal cancer patients-One center study. Rep. Pr. Oncol. Radiother. 2020, 25, 867-875. [CrossRef] [PubMed]

174. Hurwitz, H.I.; Fehrenbacher, L.; Novotny, W.; Cartwright, T.; Hainsworth, J.; Heim, W.; Berlin, J.; Baron, A.; Griffing, S.; Holmgren, E.; et al. Bevacizumab plus Irinotecan, Fluorouracil, and Leucovorin for Metastatic Colorectal Cancer. N. Engl. J. Med. 2004, 350, 2335-2342. [CrossRef]

175. Saltz, L.; Clarke, S.; Díaz-Rubio, E.; Scheithauer, W.; Figer, A.; Wong, R.; Koski, S.; Lichinitser, M.; Yang, T.-S.; Rivera, F.; et al. Bevacizumab in Combination With Oxaliplatin-Based Chemotherapy As First-Line Therapy in Metastatic Colorectal Cancer: A Randomized Phase III Study. J. Clin. Oncol. 2008, 26, 2013-2019. [CrossRef]

176. Tabernero, J.; Van Cutsem, E.; Lakomý, R.; Prausová, J.; Ruff, P.; Van Hazel, G.A.; Moiseyenko, V.M.; Ferry, D.R.; McKendrick, J.J.; Soussan-Lazard, K.; et al. Aflibercept versus placebo in combination with fluorouracil, leucovorin and irinotecan in the treatment of previously treated metastatic colorectal cancer: Prespecified subgroup analyses from the VELOUR trial. Eur. J. Cancer 2014, 50, 320-331. [CrossRef]

177. Neurath, M.F.; Fuss, I.; Pasparakis, M.; Alexopoulou, L.; Haralambous, S.; Strober, W.; Kollias, G.; Büschenfelde, K.-H.M.Z. Predominant pathogenic role of tumor necrosis factor in experimental colitis in mice. Eur. J. Immunol. 1997, 27, 1743-1750. [CrossRef]

178. Present, D.H.; Rutgeerts, P.; Targan, S.; Hanauer, S.B.; Mayer, L.; Van Hogezand, R.A.; Podolsky, D.K.; Sands, B.E.; Braakman, T.; DeWoody, K.L.; et al. Infliximab for the treatment of fistulas in patients with Crohn's disease. N. Engl. J. Med. 1999, 340, 1398-1405. [CrossRef]

179. Rutgeerts, P.; Sandborn, W.J.; Feagan, B.G.; Reinisch, W.; Olson, A.; Johanns, J.; Travers, S.; Rachmilewitz, D.; Hanauer, S.B.; Lichtenstein, G.R.; et al. Infliximab for Induction and Maintenance Therapy for Ulcerative Colitis. N. Engl. J. Med. 2005, 353, $2462-2476$. [CrossRef]

180. Melsheimer, R.; Geldhof, A.; Apaolaza, I.; Schaible, T. Remicade((R)) (infliximab): 20 years of contributions to science and medicine. Biologics 2019, 13, 139-178.

181. Baert, F.; Noman, M.; Vermeire, S.; Van Assche, G.; D’Haens, G.; Carbonez, A.; Rutgeerts, P. Influence of immunogenicity on the long-term efficacy of infliximab in Crohn's disease. N. Engl. J. Med. 2003, 348, 601-608. [CrossRef]

182. Keane, J.; Gershon, S.; Wise, R.P.; Mirabile-Levens, E.; Kasznica, J.; Schwieterman, W.D.; Siegel, J.N.; Braun, M.M. Tuberculosis

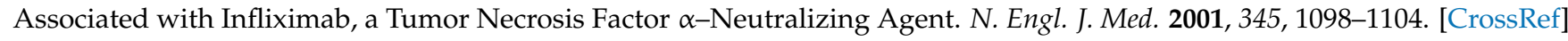
[PubMed]

183. Muller, M.; D’Amico, F.; Bonovas, S.; Danese, S.; Peyrin-Biroulet, L. TNF Inhibitors and Risk of Malignancy in Patients with Inflammatory Bowel Diseases: A Systematic Review. J. Crohn's Coliti 2020. [CrossRef]

184. Grivennikov, S.; Karin, E.; Terzic, J.; Mucida, D.; Yu, G.Y.; Vallabhapurapu, S.; Scheller, J.; Rose-John, S.; Cheroutre, H.; Eckmann, L.; et al IL-6 and Stat 3 are required for survival of intestinal epithelial cells and development of colitis-associated cancer. Cancer Cell 2009, 15, 103-113. [CrossRef] [PubMed]

185. Ito, H.; Takazoe, M.; Fukuda, Y.; Hibi, T.; Kusugami, K.; Andoh, A.; Matsumoto, T.; Yamamura, T.; Azuma, J.; Nishimoto, N. A pilot randomized trial of a human anti-interleukin-6 receptor monoclonal antibody in active Crohn's disease 2$\}$. Gastroenterology 2004, 126, 989-996. [CrossRef] [PubMed]

186. Danese, S.; Vermeire, S.; Hellstern, P.; Panaccione, R.; Rogler, G.; Fraser, G.; Kohn, A.; Desreumaux, P.; Leong, R.W.; Comer, G.M.; et al. Randomised trial and open-label extension study of an anti-interleukin-6 antibody in Crohn's disease (ANDANTE I and II). Gut 2019, 68, 40-48. [CrossRef] [PubMed]

187. Siegmund, B.; Fantuzzi, G.; Rieder, F.; Gamboni-Robertson, F.; Lehr, H.A.; Hartmann, G.; Dinarello, C.A.; Endres, S.; Eigler, A Neutralization of interleukin-18 reduces severity in murine colitis and intestinal IFN-gamma and TNF-alpha production. Am. J. Physiol. Integr. Comp. Physiol. 2001, 281, 1264-1273. [CrossRef]

188. Wirtz, S.; Becker, C.; Blumberg, R.; Galle, P.R.; Neurath, M.F. Treatment of T cell-dependent experimental colitis in SCID mice by local administration of an adenovirus expressing IL-18 antisense mRNA. J. Immunol. 2002, 168, 411-420. [CrossRef]

189. Sandborn, W.J.; Gasink, C.; Gao, L.L.; Blank, M.A.; Johanns, J.; Guzzo, C.; Sands, B.E.; Hanauer, S.B.; Targan, S.; Rutgeerts, P.; et al. Ustekinumab induction and maintenance therapy in refractory Crohn's disease. N. Engl. J. Med. 2012, 367, 1519-1528. [CrossRef]

190. Feagan, B.G.; Sandborn, W.J.; Gasink, C.; Jacobstein, D.; Lang, Y.; Friedman, J.R.; Blank, M.A.; Johanns, J.; Gao, L.-L.; Miao, Y.; et al Ustekinumab as Induction and Maintenance Therapy for Crohn's Disease. N. Engl. J. Med. 2016, 375, 1946-1960. [CrossRef] 
191. Rutgeerts, P.; Gasink, C.; Chan, D.; Lang, Y.; Pollack, P.; Colombel, J.-F.; Wolf, D.C.; Jacobstein, D.; Johanns, J.; Szapary, P.; et al. Efficacy of Ustekinumab for Inducing Endoscopic Healing in Patients With Crohn's Disease. Gastroenterology 2018, 155, 1045-1058. [CrossRef] [PubMed]

192. Sandborn, W.J.; Rutgeerts, P.; Gasink, C.; Jacobstein, D.; Zou, B.; Johanns, J.; Sands, B.E.; Hanauer, S.B.; Targan, S.; Ghosh, S.; et al. Long-term efficacy and safety of ustekinumab for Crohn's disease through the second year of therapy. Aliment. Pharmacol. Ther. 2018, 48, 65-77. [CrossRef] [PubMed]

193. Panaccione, R.; Sandborn, W.J.; Gordon, G.L.; Lee, S.D.; Safdi, A.; Sedghi, S.; Feagan, B.G.; Hanauer, S.; Reinisch, W.; Valentine, J.F.; et al. Briakinumab for treatment of Crohn's disease: Results of a randomized trial. Inflamm. Bowel. Dis. 2015, $21,1329-1340$

194. Elson, C.O.; Cong, Y.; Weaver, C.T.; Schoeb, T.R.; McClanahan, T.K.; Fick, R.B.; Kastelein, R.A. Monoclonal Anti-Interleukin 23 Reverses Active Colitis in a T Cell-Mediated Model in Mice. Gastroenterology 2007, 132, 2359-2370. [CrossRef] [PubMed]

195. Uhlig, H.H.; McKenzie, B.S.; Hue, S.; Thompson, C.; Joyce-Shaikh, B.; Stepankova, R.; Robinson, N.; Buonocore, S.; Tlaskalova-Hogenova, H.; Cua, D.J.; et al. Differential Activity of IL-12 and IL-23 in Mucosal and Systemic Innate Immune Pathology. Immunity 2006, 25, 309-318. [CrossRef]

196. Kullberg, M.C.; Jankovic, D.; Feng, C.G.; Hue, S.; Gorelick, P.L.; McKenzie, B.S.; Cua, D.J.; Powrie, F.; Cheever, A.W.; Maloy, K.J.; et al. IL-23 plays a key role in Helicobacter hepaticus-induced T cell-dependent colitis. J. Exp. Med. 2006, 203, 2485-2494. [CrossRef]

197. Almradi, A.; Hanzel, J.; Sedano, R.; Parker, C.E.; Feagan, B.G.; Ma, C.; Jairath, V. Clinical Trials of IL-12/IL-23 Inhibitors in Inflammatory Bowel Disease. BioDrugs 2020, 34, 713-721. [CrossRef]

198. Sands, B.E.; Chen, J.; Feagan, B.G.; Penney, M.; Rees, W.A.; Danese, S.; Higgins, P.D.; Newbold, P.; Faggioni, R.; Patra, K.; et al. Efficacy and Safety of MEDI2070, an Antibody Against Interleukin 23, in Patients With Moderate to Severe Crohn's Disease: A Phase 2a Study. Gastroenterology 2017, 153, 77-86.e6. [CrossRef]

199. Sandborn, W.J.; Ferrante, M.; Bhandari, B.R.; Berliba, E.; Feagan, B.G.; Hibi, T.; Tuttle, J.L.; Klekotka, P.; Friedrich, S.; Durante, M.; et al. Efficacy and Safety of Mirikizumab in a Randomized Phase 2 Study of Patients With Ulcerative Colitis. Gastroenterology 2020, 158, 537-549.e10. [CrossRef]

200. Hommes, D.W.; Mikhajlova, T.L.; Stoinov, S.; Štimac, D.; Vucelic, B.; Lonovics, J.; Zákuciová, M.; D’Haens, G.; Van Assche, G.; $\mathrm{Ba}$, S.; et al. Fontolizumab, a humanised anti-interferon gamma antibody, demonstrates safety and clinical activity in patients with moderate to severe Crohn's disease. Gut 2006, 55, 1131-1137. [CrossRef]

201. Reinisch, W.; Panés, J.; Khurana, S.; Toth, G.; Hua, F.; Comer, G.M.; Hinz, M.; Page, K.; O’Toole, M.; Moorehead, T.M.; et al Anrukinzumab, an anti-interleukin 13 monoclonal antibody, in active UC: Efficacy and safety from a phase Ila randomised multicentre study. Gut 2015, 64, 894-900. [CrossRef] [PubMed]

202. Hueber, W.; Sands, B.E.; Lewitzky, S.; Vandemeulebroecke, M.; Reinisch, W.; Higgins, P.D.; Wehkamp, J.; Feagan, B.G.; Yao, M.D.; Karczewski, M.; et al. Secukinumab, a human anti-IL-17A monoclonal antibody, for moderate to severe Crohn's disease: Unexpected results of a randomised, double-blind placebo-controlled trial. Gut 2012, 61, 1693-1700. [CrossRef] [PubMed]

203. Herrlinger, K.; Diculescu, M.; Fellermann, K.; Hartmann, H.; Howaldt, S.; Nikolov, R.; Petrov, A.; Reindl, W.; Otte, J.; Stoynov, S.; et al. Efficacy, safety and tolerability of vidofludimus in patients with inflammatory bowel disease: The ENTRANCE study. J. Crohn's Coliti 2013, 7, 636-643. [CrossRef] [PubMed]

204. Targan, S.R.; Feagan, B.; Vermeire, S.; Panaccione, R.; Melmed, G.Y.; Landers, C.; Li, D.; Russell, C.; Newmark, R.; Zhang, N.; et al. A Randomized, Double-Blind, Placebo-Controlled Phase 2 Study of Brodalumab in Patients With Moderate-to-Severe Crohn's Disease. Am. J. Gastroenterol. 2016, 111, 1599-1607. [CrossRef]

205. Lee, J.S.; Tato, C.M.; Joyce-Shaikh, B.; Gulen, M.F.; Cayatte, C.; Chen, Y.; Blumenschein, W.M.; Judo, M.; Ayanoglu, G.; McClanahan, T.K.; et al. Interleukin-23-Independent IL-17 Production Regulates Intestinal Epithelial Permeability. Immunity 2015, 43, 727-738. [CrossRef]

206. Maxwell, J.R.; Zhang, Y.; Brown, W.A.; Smith, C.L.; Byrne, F.R.; Fiorino, M.; Stevens, E.; Bigler, J.; Davis, J.A.; Rottman, J.B.; et al. Differential Roles for Interleukin-23 and Interleukin-17 in Intestinal Immunoregulation. Immunity 2015, 43, 739-750. [CrossRef] 